\title{
A MAP Kinase-Signaling Pathway Mediates Neurite Outgrowth on L1 and Requires Src-Dependent Endocytosis
}

\author{
Ralf-Steffen Schmid, Wendy M. Pruitt, and Patricia F. Maness \\ Department of Biochemistry, School of Medicine, University of North Carolina, Chapel Hill, North Carolina 27599-7260
}

\begin{abstract}
The neural cell adhesion molecule L1 mediates the axon outgrowth, adhesion, and fasciculation necessary for proper development of synaptic connections. Mutations of human L1 cause an X-linked mental retardation syndrome termed CRASH (corpus callosum hypoplasia, retardation, aphasia, spastic paraplegia, and hydrocephalus), and L1 knock-out mice display defects in neuronal process extension resembling the CRASH phenotype. Little is known about the biochemical or cellular mechanism by which L1 performs neuronal functions. Here it is demonstrated that clustering of L1 with antibodies or L1 protein in rodent B35 neuroblastoma and cerebellar neuron cultures induced the phosphorylation/activation of the mitogen-activated protein kinases (MAPKs) and extracellular signal-regulated kinases 1 and 2. MAPK activation was essential for L1-dependent neurite outgrowth, because chemical inhibitors [2-(2'-amino3'-methoxyphenyl)-oxanaphthalen-4-one and 1,4-diamino-2,3dicyano-1,4-bis(2-aminophenylthio)butadiene] of the MAPK kinase MEK strongly suppressed neurite outgrowth by cerebellar
\end{abstract}

The cell adhesion molecule $\mathrm{L} 1$ functions broadly in regulating the growth of axons in developing neurons and in fostering learning in the adult brain (Persohn and Schachner, 1990; Scholey et al., 1993; Luthi et al., 1994). L1 is localized in the plasmalemma of growth cones and processes of developing neurons, on axons of mature nonmyelinated neurons, and in Schwann cells, astrocytes, and some hematopoietic cells (for review, see Schmid and Maness, 2000). L1 knock-out mice show axon guidance errors in the corticospinal tract (Cohen et al., 1997) and corpus callosum (Demyanenko et al., 1999), misoriented dendrites of cortical pyramidal cells (Demyanenko et al., 1999), degeneration of sensory axons (Haney et al., 1999), and enlarged ventricles (Dahme et al., 1997; Demyanenko et al., 1999). Many of these features are present in humans with the X-linked mental retardation syndrome termed CRASH (corpus callosum hypoplasia, retardation, aphasia, spastic paraplegia, and hydrocephalus), resulting from L1 gene mutations (Fransen et al., 1997).

Little is known about the mechanism by which L1 directs axonal growth or guidance, but the structural features of L1

\footnotetext{
Received Feb. 1, 2000; revised March 15, 2000; accepted March 17, 2000.

This research was supported by National Institutes of Health Grant NS 26620 to P.F.M. and by a grant from the University of North Carolina Medical Alumni Association to R.-S.S. We are grateful to Dr. Ron Graff for producing the L1-B35 cell line and to Drs. John Hemperly, Keith Burridge, Channing Der, and Michael Schaller for providing reagents and advice. We thank Drs. Melanie Cobb, Sara Courtneidge, Richard Cerione, Deborah Morrison, Al Baldwin, Marty Mayo, and Shelton Earp for plasmids.

Correspondence should be addressed to Dr. Patricia F. Maness, University of North Carolina, Department of Biochemistry CB\#7260, Chapel Hill, NC 275997260. E-mail: srclab@med.unc.edu.

Copyright (C) 2000 Society for Neuroscience $\quad 0270-6474 / 00 / 204177-12 \$ 15.00 / 0$
}

neurons on L1. The nonreceptor tyrosine kinase $p p 60^{c-s r c}$ was required for L1-triggered MAPK phosphorylation, as shown in src-minus cerebellar neurons and by expression of the kinaseinactive mutant Src(K295M) in B35 neuroblastoma cells. Phosphatidylinositol 3-kinase (PI3-kinase) and the small GTPase p2 $1^{\text {rac }}$ were identified as signaling intermediates to MAPK by phosphoinositide and Rac-GTP assays and expression of inhibitory mutants. Antibody-induced endocytosis of L1, visualized by immunofluorescence staining and confocal microscopy of B35 cells, was blocked by expression of kinase-inactive Src(K295M) and dominant-negative dynamin(K44A) but not by inhibitors of MEK or PI3-kinase. Dynamin(K44A) also inhibited L1 antibody-triggered MAPK phosphorylation. This study supports a model in which $\mathrm{pp}^{\mathrm{c}} \mathrm{o}^{\mathrm{s} s \mathrm{~s}}$ regulates dynamin-mediated endocytosis of L1 as an essential step in MAPK-dependent neurite outgrowth on an L1 substrate.

Key words: neurite outgrowth; endocytosis; neural cell adhesion molecule; signal transduction; Src; MAP kinase; PI3-kinase suggest that it may differ from that used by other classes of receptors to stimulate neurite outgrowth. The L1 extracellular region mediates homophilic (L1-L1) and heterophilic binding via its six immunoglobulin-like and five fibronectin type III domains (Appel et al., 1993; Zhao et al., 1998). Its short cytoplasmic region of 110 amino acids lacks a tyrosine kinase domain but contains an actin-interaction domain (Dahlin-Huppe et al., 1997), an ankyrinbinding region (Davis and Bennett, 1994), and a neuronal-specific sequence, RSLE, which targets L1 to axons (Kamiguchi and Lemmon, 1998). This motif is also involved in binding adaptor protein 2, a clathrin adaptor, which enables L1 to be internalized in growth cones via receptor-mediated endocytosis (Kamiguchi et al., 1998). It is not known whether endocytosis of L1 plays any role in the biological functions of L1 or merely directs L1 to intracellular pathways for degradation.

A requirement for the nonreceptor tyrosine kinase $\mathrm{pp} 60^{c-s r c}$ in L1-mediated neurite outgrowth has been identified in $s r c$-minus neurons (Ignelzi et al., 1994), but how pp60 ${ }^{c-s r c}$ regulates neurite growth on L1 is not known. pp60 6 -src is tethered by N-terminal myristylation to the cytoplasmic face of the plasma membrane and interacts functionally with a variety of receptor types (Maness et al., 1996). On the basis of the recent finding that pp60 $60^{c-s r c}$ is required for endocytosis and signaling of the $\beta$-adrenergic receptor (Ahn et al., 1999), we have investigated the hypothesis that $\mathrm{pp} 60^{c-s r c}$ regulates the internalization of L1 as a critical determinant of L1-mediated neurite outgrowth. Like the $\beta$-adrenergic receptor, L1 clustering activates mitogen-activated protein kinases (MAPKs) in neuronal cells (Schmid et al., 1997; Schaefer et al., 1999), but it is not known whether MAPK has a 
role in neurite outgrowth or other physiological functions of L1. L1 triggering also modulates intracellular levels of phosphoinositides, $\mathrm{pH}$, and $\mathrm{Ca}^{2+}$ (Schuch et al., 1989; von Bohlen und Halbach et al., 1992) and activates tyrosine phosphatases in growth cones (Atashi et al., 1992; Klinz et al., 1995), suggesting that an array of signaling intermediates may coordinate the complex intracellular program that allows growth cones to navigate through the developing brain and form synaptic connections.

Here we demonstrate that MAPK activation triggered by L1 in neuronal cells is required for neurite outgrowth on L1 and is mediated via pp60-src and the small GTPase $\mathrm{p} 21^{r a c}$ and phosphatidylinositol 3-kinase (PI3-kinase). Furthermore, it is shown that pp $60^{c-s r c}$ functions by controlling dynamin-mediated endocytosis of L1 as an essential step in MAPK activation. This L1 pathway has the potential to regulate both actin cytoskeletal dynamics in growth cones and gene expression in the nucleus, events that may coordinate to regulate the growth and navigation of neuronal processes.

\section{MATERIALS AND METHODS}

Antibodies and plasmids. Antibodies used in this research were mouse monoclonal antibody Neuro4 against the L1 extracellular region (the gift of John Hemperly, Becton Dickinson); monoclonal antibody HA.11 directed against the hemagglutinin (HA)-epitope tag (Babco, Richmond, CA); anti-active MAPK polyclonal antibody (Promega, Madison, WI) specific for dually phosphorylated, activated MAPK; extracellular signalregulated kinase 1 (ERK1) polyclonal antibody K-23 and Raf-1 and B-Raf antibodies (Santa Cruz Biotechnology, Santa Cruz, CA); and anti-active p38 antibody (New England Biolabs, Beverly, MA). The following cDNAs were subcloned into the vector pcDNA3 for expression in B35 neuroblastoma cells: Fak-related nonkinase (FRNK) and Fak(397F) (Michael Schaller, University of North Carolina, Chapel Hill, NC); Ras(15A), RhoA(19N), Rac1(17N), and Cdc42(17N) (Channing Der, University of North Carolina, Chapel Hill, NC); Src(K295M) (Sara Courtneidge, Sugen); PI3-kinase $\Delta$ p85 (A. Baldwin and M. Mayo, University of North Carolina, Chapel Hill, NC); dynamin(K44A) (Marc Caron, Duke University, Durham, NC); c-Raf-1(621A and R89L) and B-Raf (621A and R89L) (D. Morrison, National Cancer Institute, Frederick, MD); and HA-tagged ERK2 (Melanie Cobb, University of Texas Southwestern Medical School, Dallas, TX). Other plasmids used encoded enhanced cyan fluorescence protein (Invitrogen, San Diego, CA) and glutathione $S$-transferase (GST) plasmids encoding the c-Jun (1-79)GST fusion protein (Shelton Earp, University of North Carolina, Chapel Hill, NC) and the Rac-binding domain (RBD)-GST fusion protein (Richard Cerione, Cornell University, Ithaca, NY).

Cell cultures and methods of L1 clustering. To produce a cell line stably expressing human L1 (with RSLE), we transfected rat B35 neuroblastoma cells (Schubert et al., 1974) with human neuronal L1 cDNA in the pcDNA3 vector (gift of John Hemperly, Becton Dickinson). After selection in $0.5 \mathrm{mg} / \mathrm{ml} \mathrm{G} 418,17$ clones were assayed for L1 expression by Western blotting, and L1 localization on the cell surface was verified by indirect immunofluorescence staining with Neuro4 antibodies. One clone (designated B35-L1) exhibiting intermediate levels of L1 expression was chosen for the studies reported here. B35-L1 cells were maintained in DMEM containing $10 \%$ fetal bovine serum (FBS; HyClone, Logan, UT) and G418 $(0.25 \mathrm{mg} / \mathrm{ml})$. Primary cultures of mouse cerebellar neurons were prepared from postnatal day 8 Sv129/C6B57 hybrid mice by the method of Schnitzer and Schachner (1981) and grown in DMEM with $10 \%$ FBS (HyClone), $25 \mathrm{~mm} \mathrm{KCl}$, and penicillin/streptomycin. The medium was replaced with OptiMEM (Life Technologies, Gaithersburg, $\mathrm{MD}$ ), and cells were incubated for $8 \mathrm{hr}$ before initiating signaling. For clustering of L1 on B35-L1 cells and cerebellar neurons, L1 monoclonal antibody Neuro4 $(30 \mu \mathrm{g})$ or L1-Fc fusion proteins $(50 \mu \mathrm{g})$ were preincubated with $\mathrm{F}\left(\mathrm{ab}^{\prime}\right)_{2}$ fragments of secondary antibodies raised against $\mathrm{Fc}$ fragments of mouse or human $\operatorname{IgG}$ for $1 \mathrm{hr}$ at $4^{\circ} \mathrm{C}$ in $50 \mu \mathrm{l}$ of OptiMEM. The complexes were added directly to cells in a $60 \mathrm{~mm}$ dish containing $1 \mathrm{ml}$ of medium at $37^{\circ} \mathrm{C}$. Clustering of L1 into patches on the cell surface was observed by indirect immunofluorescence staining (data not shown).

MAPK phosphorylation assays. Cells were stimulated with the indicated L1 antibodies or fusion proteins, rinsed once with cold HBSS, and extracted in Nonidet P-40 (NP-40) lysis buffer containing 1\% NP-40,
$0.25 \%$ (w/v) Na-deoxycholate, 50 mм HEPES, pH 7.4, 137 mm NaCl, 1 $\mathrm{mm}$ Na-EDTA, $10 \mathrm{~mm}$ NaF, $1 \mathrm{~mm}$ Na-orthovanadate, $10 \mathrm{~mm}$ $p$-nitrophenylphosphate, $1 \mathrm{~mm}$ phenylmethylsulfonyl fluoride, $10 \mathrm{~mm}$ $\beta$-glycerophosphate, $10 \mu \mathrm{g} / \mathrm{ml}$ leupeptin, $0.1 \mathrm{TIU} / \mathrm{ml}$ aprotinin, $1 \mu \mathrm{g} / \mathrm{ml}$ pepstatin, $2 \mathrm{~nm}$ calyculin A, and $10 \%$ (v/v) glycerol. Lysates were clarified by centrifugation at $14,000 \times g$ for $20 \mathrm{~min}$ at $4^{\circ} \mathrm{C}$. Protein concentration was determined using the bicinchoninic acid assay (Pierce, Rockford, IL). Proteins in cell extracts were separated by SDS-PAGE and transferred to a nitrocellulose membrane. The membrane was blocked for $2 \mathrm{hr}$ in $1 \%$ bovine serum albumin (BSA) in Tris-buffered saline containing $0.05 \%$ Tween 20 (TTBS) and then incubated overnight at $4^{\circ} \mathrm{C}$ either with anti-active MAPK antibodies or p38 MAPK antibodies in 1\% BSA in TTBS. After washing in TTBS, the membrane was incubated with goat anti-rabbit IgG horseradish peroxidase conjugate in TTBS for $1 \mathrm{hr}$. The membrane was again washed in TTBS, and immune complexes were detected using enhanced chemiluminescence (ECL; NEN) with Sterling $\mathrm{x}$-ray film (BioWorld). Membranes were stripped and reprobed in the same manner with ERK antibodies to detect total ERK protein.

For assaying phosphorylation of HA-tagged ERK2, B35-L1 cells were transfected for transient expression with an HA-tagged ERK2 plasmid with or without plasmids expressing dominant-negative mutants. Subconfluent cultures were transfected in $60 \mathrm{~mm}$ dishes containing OptiMEM using Lipofectamine according to the manufacturer's instructions (Life Technologies). Signaling experiments were initiated 36-40 hr after transfection. Cells were lysed in NP-40 lysis buffer, and HA-tagged ERK2 was immunoprecipitated from cell extracts $(500 \mu \mathrm{g})$ with anti-HA antibody (Babco) for $1.5 \mathrm{hr}$, followed by Protein G-Sepharose for $0.5 \mathrm{hr}$ at $4^{\circ} \mathrm{C}$. Immune complexes were washed in lysis buffer and subjected to SDS-PAGE, followed by immunoblotting with anti-active MAPK antibody. For all assays, the exposed bands on x-ray film were quantitated by densitometric scanning and analysis with Image-Quant NT software. MEK inhibitors [2-(2'-amino-3'-methoxyphenyl)-oxanaphthalen-4-one (PD98059; $50 \mu \mathrm{M}$; New England Biolabs) and 1,4-diamino-2,3-dicyano1,4-bis(2-aminophenylthio)butadiene (U0126; $10 \mu \mathrm{M}$; Promega)] or a PI3-kinase inhibitor [Ly294002 (10-20 $\mu \mathrm{g}$; Promega)] dissolved in dimethylsulfoxide (DMSO; <0.01\%) was added to cells for $1 \mathrm{hr}$ before signal initiation. The Rho inhibitor C3 botulinum endotoxin $(20 \mu \mathrm{g})$ was added with Lipofectamine $(5 \mu \mathrm{g})$ to cells for $4 \mathrm{hr}$ before stimulation. Control cultures received the same concentration of DMSO or Lipofectamine.

For assaying the activity of c-Jun N-terminal kinase (JNK), cell extracts $(100 \mu \mathrm{g}$ of protein) in NP-40 lysis buffer were incubated with c-Jun (1-79)-GST fusion protein for $4 \mathrm{hr}$ at $4^{\circ} \mathrm{C}$. Immune complexes were washed twice with lysis buffer and twice with kinase buffer $(25 \mathrm{~mm}$ HEPES, pH 7.4, $25 \mathrm{~mm} \mathrm{MgCl}_{2}, 25 \mathrm{~mm} \beta$-glycerophosphate, $2 \mathrm{~mm}$ dithiothreitol, $0.1 \mathrm{~mm}$ Na-orthovanadate, and $2 \mathrm{~mm} p$-nitrophenylphosphate) and then incubated in kinase buffer with $50 \mu \mathrm{M}$ ATP and 0.5 $\mu \mathrm{Ci}$ of $\left[\gamma^{32} \mathrm{P}\right] \mathrm{ATP}(\mathrm{ICN})$ at $30^{\circ} \mathrm{C}$ for $30 \mathrm{~min}$. Proteins were separated on SDS-PAGE. The dried gel was exposed to $\mathrm{x}$-ray film, and exposed bands were quantitated by densitometric scanning and analysis with ImageQuant NT software.

Assay of phosphoinositides. PI3-kinase activity was assayed by immunoprecipitating phosphotyrosine-modified PI3-kinase from cell extracts with phosphotyrosine antibodies and measuring the production of phosphoinositides from phosphatidylinositol in an immune complex kinase assay (Myers et al., 1993). Cell extracts $(800 \mu \mathrm{g})$ were incubated with phosphotyrosine antibody $4 \mathrm{G} 10$ for $8 \mathrm{hr}$ at $4^{\circ} \mathrm{C}$ and then for $1 \mathrm{hr}$ with Protein G-Sepharose. Immunoprecipitates were collected and washed twice with buffers I, II, and III (buffer I, $20 \mathrm{~mm}$ Tris, $\mathrm{pH} 7.4,150 \mathrm{~mm}$ $\mathrm{NaCl}, 1 \% \mathrm{NP}-40$, and $100 \mu \mathrm{M}$ Na-orthovanadate; buffer II, $100 \mathrm{~mm}$ Tris, pH 7.4, $500 \mathrm{~mm} \mathrm{LiCl}$, and $100 \mu \mathrm{M}$ Na-orthovanadate; and buffer III, 10 mm Tris, pH 7.4, $100 \mathrm{~mm} \mathrm{NaCl}$, and $100 \mu \mathrm{M}$ Na-orthovanadate). Phosphatidylinositol $(0.5 \mathrm{mg} / \mathrm{ml}$; Avanti Polarlipids) was sonicated in $20 \mathrm{~mm}$ Tris, $\mathrm{pH} \mathrm{7.4,} \mathrm{and} 1 \mathrm{~mm}$ Na-EGTA and incubated with the immune complexes for $10 \mathrm{~min}$ at room temperature in kinase reaction buffer (total volume of $50 \mu \mathrm{l}$ ) containing $20 \mu \mathrm{M}$ ATP, $1 \mu \mathrm{Ci}$ of $\left[\gamma^{32} \mathrm{P}\right] \mathrm{ATP}(3000$

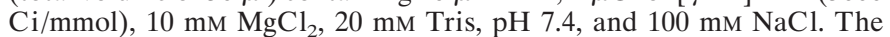
reaction was terminating by adding $6 \mathrm{~N} \mathrm{HCl}(15 \mu \mathrm{l})$ and $1: 1(\mathrm{v} / \mathrm{v})$ chloroform:methanol $(120 \mu \mathrm{l})$. Samples were vortexed for $30 \mathrm{sec}$ and centrifuged at $10,000 \times g$ for $1 \mathrm{~min}$. Aliquots $(30 \mu \mathrm{l})$ of the chloroform phase were spotted on SilicaG60 plates (Whatman, Maidstone, UK) and subjected to thin-layer chromatography in chloroform:methanol:25\% (w/w) $\mathrm{NH}_{4} \mathrm{OH}$ :water (60:47:2:11.3, v/v/v/v). Commercially available phosphatidylinositol 4-phosphate (PIP; Sigma, St. Louis, MO) was used to indicate the location of the product. The plate was dried and exposed to 
x-ray film. Phospholipids were visualized by incubating the thin-layer plate with iodine vapors, and radioactive spots were scraped from the plate and quantitated for ${ }^{32} \mathrm{P}$ incorporation in a scintillation counter.

Assays for GTP-bound $p 21^{\text {rac }}$ and Raf kinase activity. For measurement of activated, GTP-bound Rac (Bagrodia et al., 1998), B35-L1 cells were stimulated with $\mathrm{L} 1$ antibodies or normal $\mathrm{IgG}$ as described; then lysates $(500 \mu \mathrm{g})$ were incubated for $30 \mathrm{~min}$ at $4^{\circ} \mathrm{C}$ with $20 \mu \mathrm{g}$ of a purified GST fusion protein (RBD-GST) consisting of the Rac-binding domain of PAK1 together with glutathione Sepharose. RBD-GST binds only to the activated form of Rac (Rac-GTP) but not to inactive Rac-GDP. RBD-GST/Rac-GTP complexes were collected by centrifugation and analyzed by SDS-PAGE and Western blotting with anti-Rac antibodies (Transduction Laboratories, Lexington, KY).

To assay Raf activation, we subjected lysates in NP-40 lysis buffer ( 800 $\mu \mathrm{g})$ to immunoprecipitation using polyclonal antibodies specific for $\mathrm{c}-\mathrm{Raf}$ or B-Raf (Santa Cruz Biotechnology) and Protein G-Sepharose. In a coupled assay measuring myelin basic protein (MBP) phosphorylation (Upstate Biotechnology, Lake Placid, NY), Raf immune complexes were preincubated with inactive MEK and MAPK for $30 \mathrm{~min}$ at $37^{\circ} \mathrm{C}$ and then with MBP and $\left[\gamma^{32} \mathrm{P}\right] \mathrm{ATP}$ for $10 \mathrm{~min}$ at $37^{\circ} \mathrm{C}$. MBP was adsorbed to Whatman $\mathrm{P} 81$ paper and quantitated for incorporation of radioactivity by scintillation counting. An activated form of Raf provided by the manufacturer was used as a positive control. The amounts of Raf immunoprecipitated were determined in parallel by immunoblotting with Raf antibodies.

Measurement of neurite outgrowth. Cultures of mouse cerebellar neurons consisting chiefly of granule cells were prepared from postnatal day 7 or 8 pups by the method of Schnitzer and Schachner (1981). Immunoaffinity-purified L1 protein from adult mice brain was applied in $10 \mu \mathrm{l}$ spots onto nitrocellulose-coated plastic coverslips $\left(22 \times 22 \mathrm{~mm}^{2}\right)$ in $35 \mathrm{~mm}$ Petri dishes as described (Ignelzi et al., 1994). After blocking with $1 \%$ bovine serum albumin, $2 \times 10^{6}$ cerebellar cells were added per coverslip in $2 \mathrm{ml}$ of basal medium with Eagle's salts (Life Technologies) with $10 \%$ heat-inactivated horse serum, $2.5 \mathrm{gm} / 1$ glucose, and penicillin/ streptomycin. No neurons attached to uncoated areas of the nitrocellulose. The MEK inhibitors PD98059 and U0126 were dissolved in DMSO and added at the time of plating at 50 or $10 \mu \mathrm{M}$ final concentration, respectively, resulting in a final concentration of $0.1 \%$ DMSO. Control cultures received the same concentration of DMSO. Cells were fixed after $24 \mathrm{hr}$ with $4 \%$-formaldehyde and then mounted on microscope slides. The length of the longest neurite per cell was measured using a microscope-mounted image processor with cursor overlay. Only neurites longer than $\sim 10 \mu \mathrm{m}$ and not in contact with other cells were measured. Neuron attachment to L1 was assayed by counting at least 100 cells from 30 or more randomly selected fields. Data were obtained from three independent experiments.

Immunofluorescence staining for endocytosis of L1. For experiments in which cell surface L1 and endocytosed L1 were differentially labeled in living cells, a modification of the method of Kamiguchi et al. (1998) was used. Rat B35-L1 neuroblastoma cells (20,000 cells/well) were plated in LabTek II chamber slides (Nunc, Naperville, IL) coated with poly-Dlysine. After $24 \mathrm{hr}$, cells were transfected using Lipofectamine with a plasmid encoding enhanced cyan fluorescence protein $(0.15 \mu \mathrm{g}$ of cDNA) together with a plasmid expressing one of the following $(0.25 \mu \mathrm{g}$ of cDNA): wild-type c-Src, kinase-inactive $\operatorname{Src}(\mathrm{K} 295 \mathrm{M})$, dominant-negative dynamin(K44A), or dominant-negative PI3-kinase $(\Delta \mathrm{p} 85)$. At $24 \mathrm{hr}$ after the start of transfection, cells were incubated for $45 \mathrm{~min}$ at $37^{\circ} \mathrm{C}$ with 25 $\mu \mathrm{g} / \mathrm{ml}$ Neuro4 IgG or normal mouse IgG to induce endocytosis. Cells were washed with cold DMEM and then incubated with goat anti-mouse IgG conjugated to rhodamine for $30 \mathrm{~min}$ at $4^{\circ} \mathrm{C}$ to label $\mathrm{L} 1$ on the cell surface. The cells were rinsed with HBSS and fixed in $4 \%$ $p$-formaldehyde for $30 \mathrm{~min}$. After washing cells once with $0.1 \mathrm{~mm}$ glycine in PBS and twice with PBS, cells were blocked with goat anti-mouse IgG for $1 \mathrm{hr}$ at $4^{\circ} \mathrm{C}$. After rinsing once in cold PBS, the cells were again fixed in $4 \% p$-formaldehyde for $10 \mathrm{~min}$ at room temperature. Cells were washed once with $0.1 \mathrm{~mm}$ glycine in PBS and twice with PBS, and the membrane was permeabilized with $0.1 \%$ Triton X-100 in PBS containing $10 \%$ goat serum for $1 \mathrm{hr}$ at room temperature. Cells were washed once with PBS and incubated with anti-mouse IgG conjugated to fluorescein isothiocyanate (FITC) for $1 \mathrm{hr}$ to label cytoplasmic L1. After additional washes, slides were mounted with Vectashield. Cells were viewed in a Zeiss LSM10 confocal laser microscope equipped with an argon laser (excitation lines of 488 and $514 \mathrm{~nm}$ ) resulting in an optical thickness of $0.5 \mu \mathrm{m}$ at the University of North Carolina Microscopy Services Facility, Department of Pathology (Chapel Hill, NC; Dr. Bob Bagnell, Director).
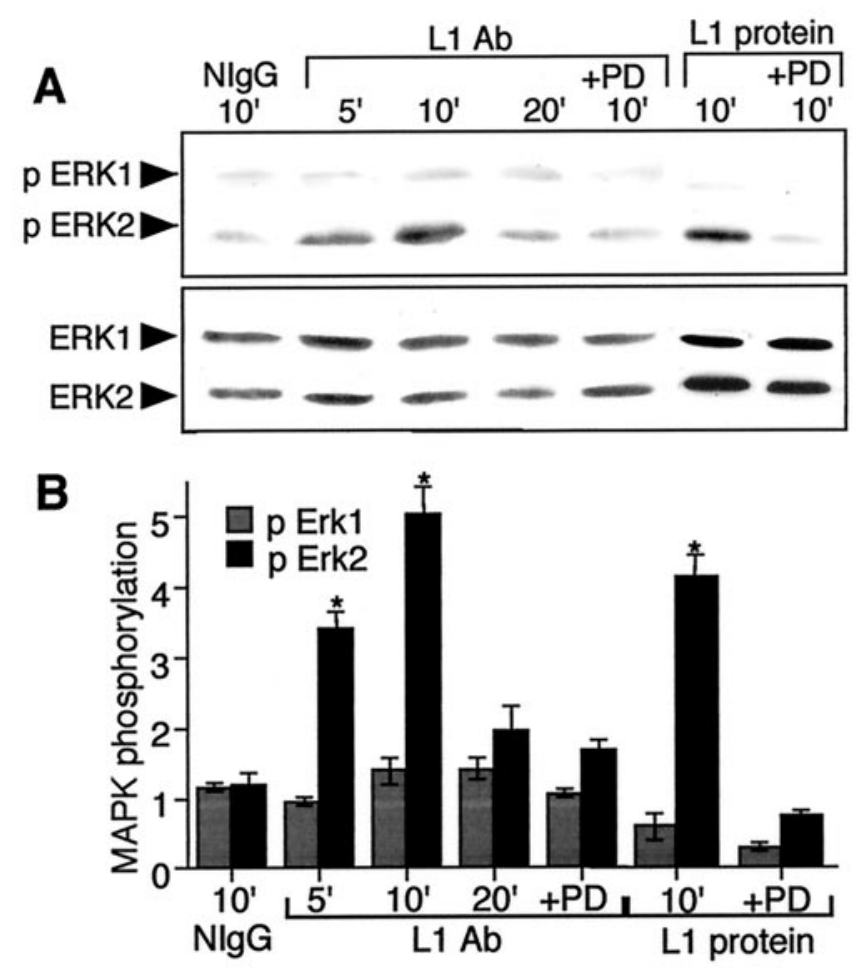

Figure 1. Clustering of L1 in cerebellar neurons activates ERK2. A, Top, Cerebellar cultures were incubated with nonimmune mouse $\operatorname{IgG}(\mathrm{NIgG})$, monoclonal antibodies against L1 (Neuro4) complexed with $\mathrm{F}\left(\mathrm{ab}^{\prime}\right)_{2}$ fragments of anti-mouse $\operatorname{IgG}(L 1 A b)$, or L1-Fc fusion protein complexed with $\mathrm{F}\left(\mathrm{ab}^{\prime}\right)_{2}$ fragments of anti-human IgG (L1 protein). Where indicated $(+P D)$, cells were treated with the MEK inhibitor PD98059 $(P D ; 25 \mu \mathrm{M})$. Cell extracts were subjected to SDS-PAGE and immunoblotting with anti-active MAPK antibodies specific for phosphorylated ERKs ( $p E R K 1$ and $p E R K 2$ ). Bottom, The same nitrocellulose filter was stripped and reblotted with antibodies recognizing phosphorylated and nonphosphorylated ERK proteins (ERK1 and ERK2). This experiment was repeated twice with similar results. $B$, Densitometric quantification of the ERK phosphorylation in $A$ is shown in arbitrary units of phosphorylation relative to that of the nonimmune IgG control. Error bars indicate SEs based on three experiments; an asterisk denotes statistical significance $(p<0.05)$.

\section{RESULTS}

\section{L1 clustering activates the MAPK pathway in cerebellar neurons}

L1 signal transduction was investigated in primary cultures of mouse cerebellar neurons, which express endogenous L1 and are comprised of $>90 \%$ granule cells (Schnitzer and Schachner, 1981). Signaling by cell adhesion molecules of the Ig superfamily, such as neural cell adhesion molecule (NCAM), integrins, and certain receptor tyrosine kinases, is initiated by the clustering of receptors with multivalent ligands or antibodies (Heldin, 1995). L1 molecules were clustered on the surface of cerebellar neurons with antibodies against the L1 extracellular domain; then cell lysates were analyzed by immunoblotting with phospho-specific MAPK antibodies recognizing a dually phosphorylated/activated form of the extracellular-regulated kinases ERK1 and ERK2. These MAP kinases are activated by dual phosphorylation of Thr 202 and Tyr 204 (Crews et al., 1992; Marshall, 1994). L1 clustering in cerebellar neurons stimulated ERK2 dual phosphorylation fivefold, increasing rapidly within 5-10 min and then declining to nearly basal levels by 20 min (Fig. 1). The decline in phosphory- 


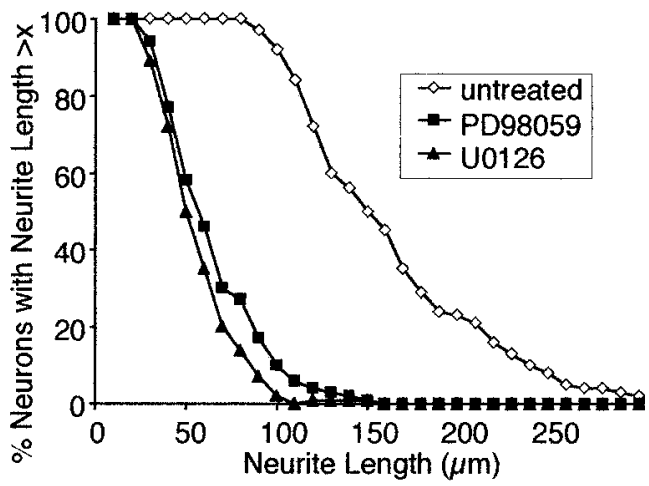

Figure 2. Effect of MEK inhibitors on L1-dependent neurite outgrowth by cerebellar neurons. Mouse cerebellar neurons were plated on purified L1 protein adsorbed to nitrocellulose-coated coverslips and allowed to extend neurites for $24 \mathrm{hr}$ without or with MEK inhibitors $(50 \mu \mathrm{M}$ PD98059 or $10 \mu \mathrm{M}$ U0126). Cells were fixed, neurite lengths were measured, and results were plotted in a neurite length distribution curve. Two hundred or more cells were analyzed for each condition (see Table 1 for additional data). This experiment was repeated twice with similar results.

lation could be caused by activation of a dual specificity tyrosine/ threonine phosphatase such as MAPK phosphatase (MKP-1) (Fuller et al., 1997) or L1-triggered phosphatase activities present in a subcellular fraction enriched in growth cone membranes (Klinz et al., 1995). L1 clustering did not induce phosphorylation of ERK1 in the cerebellar neuron cultures even though similar levels of ERK1 and ERK2 were indicated by immunoblotting with antibodies against ERK1 and ERK2 protein (Fig. 1A). Nonimmune IgG complexes had no effect on ERK phosphorylation. Multivalent L1 protein, consisting of the L1 extracellular region fused to the Fc portion of human $\mathrm{IgG}$, also stimulated the phosphorylation of ERK2 approximately four- to fivefold in cerebellar neurons with kinetics similar to that induced by L1 antibody complexes (Fig. 1). ERK2 phosphorylation in cerebellar neurons induced by cross-linked L1 antibodies or L1-Fc protein was effectively inhibited by the inhibitor PD98059, which is specific for MEK (MAP kinase kinase) (Fig. 1). PD98059 binds the inactive form of MEK1 and to a lesser extent MEK2, preventing the MEK activation required for MAPK phosphorylation (Alessi et al., 1995).

\section{An intact MAPK pathway is required for neurite outgrowth on L1}

To determine whether the MAPK pathway participated in L1directed neurite outgrowth, primary cultures of mouse cerebellar neurons (postnatal day 7-8) were analyzed for neurite outgrowth on purified mouse L1 protein adsorbed to nitrocellulose-coated dishes as described previously (Ignelzi et al., 1994). L1-stimulated neurite outgrowth was inhibited by the MEK inhibitors PD98059 and U0126 (Fig. 2, Table 1). Mean neurite length decreased 56\% in the presence of PD98059 and 66\% with U0126 (Fig. 2). U0126 was slightly more effective than PD98059, probably because U0126 inhibits active and inactive forms of MEK (Favata et al., 1998). The residual neurite outgrowth observed in the presence of MEK inhibitors suggested that there may be both MAPKdependent and -independent pathways for neurite growth on L1. Neither PD98059 nor U0126 affected cerebellar neuron attachment to purified L1 protein (Table 1; Cells $/ \mathrm{mm}^{2}$ ), the ability of cerebellar neurons to initiate neurite growth (Table 1; Cells with neurites $/ \mathrm{mm}^{2}$; \% cells with neurites), or the morphology of the neurons. Cells did not adhere to or extend neurites on areas of the nitrocellulose-coated dishes without L1 protein. Effects on fasciculation could not be evaluated in these sparsely plated cultures. These results reveal a functional role for the MEKMAPK pathway in L1-dependent neurite outgrowth by cerebellar neurons.

\section{L1 activates ERK1 and ERK2 in B35-L1 neuroblastoma cells}

The rat neuroblastoma cell line B35 (Schubert et al., 1974) is a useful CNS model for investigating signaling pathways of neural cell adhesion molecules (Schmid et al., 1999). The B35 cell line displays differentiated neuronal properties such as membrane excitability and expression of enzymes for neurotransmitter metabolism (Schubert et al., 1974) and is more easily transfected than primary neurons. B35 cells express little or no L1 as detected by immunoblotting and immunofluorescence staining with L1 antibodies. To define the L1-signaling pathway for MAPK activation further, a B35 cell line was generated that stably expressed the RSLE-containing neuronal isoform of L1 (B35-L1 cells).

L1 molecules were clustered on the surface of B35-L1 cells with L1 antibody complexes; then cell lysates were analyzed for dual phosphorylation of endogenous MAPKs by immunoblotting with phospho-specific MAPK antibodies. Phosphorylation of both ERK1 and ERK2 increased four- to fivefold within $10 \mathrm{~min}$ of L1 clustering, whereas nonimmune IgG had no effect (Fig. 3A,B). Phosphorylation was rapid and transient with similar kinetics for ERK1 and ERK2. Clustering of L1 on the cell surface was necessary for MAPK activation, because monovalent Fab fragments of L1 antibodies did not induce ERK phosphorylation (data not shown). The ability of L1 to stimulate phosphorylation of ERK1 and ERK2 in B35-L1 cells, in contrast to the phosphorylation of only ERK1 in cerebellar neurons, suggested that these pathways were differentially regulated. Similar results were obtained during NCAM stimulation in cerebellar neurons and B35 cells expressing NCAM140 (Schmid et al., 1999). Selective activation of ERK2 and not ERK1 in neuronal cells also occurs during stimulation of protein kinase $\mathrm{C}$ or NMDA receptors (English and Sweatt, 1996). Differential MAPK regulation was characterized previously in yeast in which mating and pseudohyphal differentiation are independently controlled by the MAPKs Fus3 and Kss1 (Madhani et al., 1997).

To address the specificity of L1 activation of the MAPKsignaling pathway, B35-L1 cells were assayed for L1-dependent phosphorylation of the MAP kinases, JNK, and p38, which are activated in response to multiple cellular stressors (Waskiewicz and Cooper, 1995). No increase of JNK phosphorylation was observed within 5-20 min of L1 clustering, whereas sorbitoltreated cells as a positive control showed prominent JNK activity (Fig. 3C). Similarly, the phosphorylation of p38 MAPK was not increased over basal levels compared with anisomycin-treated cells as positive controls (Fig. 3D).

\section{L1 activates the MAPK pathway via PI3-kinase and Rac}

To investigate whether L1 clustering activated PI3-kinase in L1 antibody-triggered B35-L1 cells, the production of phosphoinositides by PI3-kinase was quantitatively determined. During activation, PI3-kinase becomes phosphorylated on tyrosine and can be immunoprecipitated with phosphotyrosine antibodies. Incubation of immune complexes from L1 antibody-stimulated B35-L1 cells with phosphatidylinositol and $\left[\gamma^{32} \mathrm{P}\right]$ ATP produced radiolabeled phosphatidylinositol 3-phosphate, which was sepa- 
Table 1. Inhibition of neurite outgrowth on L1 by MEK inhibitors

\begin{tabular}{llllll} 
& $\begin{array}{l}\text { Mean neurite length } \\
(\mu \mathrm{m} \pm \mathrm{SEM})\end{array}$ & $n$ & Cells $/ \mathrm{mm}^{2}$ & $\begin{array}{l}\text { Cells with } \\
\text { neurites } / \mathrm{mm}^{2}\end{array}$ & $\begin{array}{l}\text { Cells with } \\
\text { neurites }(\%)\end{array}$ \\
\hline Untreated & $152 \pm 12^{*}$ & 253 & 38 & 34 & 90 \\
PD98059 $(50 \mu \mathrm{M})$ & $67 \pm 4^{*}$ & 264 & 36 & 33 & 91 \\
U0126 $(10 \mu \mathrm{M})$ & $52 \pm 1^{*}$ & 200 & 35 & 32 & 90
\end{tabular}

$n$ represents the number of cells measured for mean neurite length. Mean neurite lengths were obtained in three independent experiments. More than 200 cells were scored for neurite length in each condition.

* Statistically significant differences in means of treated and untreated samples using a $t$ test $(p<0.05)$.

rated from reactants by thin-layer chromatography (Fig. 4A). The amount of activated PI3-kinase increased two- to threefold within 3-8 min after antibody triggering. A similar extent of increase in PI3-kinase activity occurs in cells treated with epidermal growth factor (EGF), platelet-derived growth factor, or phorbol esters and is effective in mediating their physiological functions (Conricode, 1995; Nave et al., 1996; Cross et al., 1997). To determine whether PI3-kinase was involved in regulating L1-triggered ERK phosphorylation, a dominant-negative PI3-kinase mutant $(\Delta \mathrm{p} 85)$ was cotransfected with HA-ERK2 for transient expression in B35-L1 cells. This dominant inhibitory mutant contains a deletion in the PI3-kinase regulatory subunit (p85) that abolishes its binding to the catalytic subunit (p110) (Hara et al., 1994). Stimulation of B35-L1 cells expressing this mutant with L1 antibodies resulted in complete inhibition of ERK2 phosphorylation (Fig. $4 B$ ). Treatment of B35-L1 cells with $10 \mu \mathrm{M}$ Ly294002, a selective chemical inhibitor of PI3-kinase (Vlahos et al., 1994), prevented L1 antibody-induced phosphorylation of endogenous ERK1 and ERK2 (Fig. 4D).

$\mathrm{Rac}$ and $\mathrm{Cdc} 42$ are members of the Rho family of small GTPases that regulate actin cytoskeletal dynamics (Ridley et al., 1992), signal to JNK (Vojtek and Cooper, 1995), and cause cross-cascade activation of the ERK pathway (Frost et al., 1997). PI3-kinase contributes to the activation of Rac and $\mathrm{Cdc} 42$ by providing phosphoinositides that bind the plextrin homology domain of specific guanine nucleotide exchange factors (GEFs) (Quilliam et al., 1995). To investigate the role of small GTPases in L1-stimulated MAPK activation, B35-L1 cells were cotransfected with HA-tagged ERK2 and dominant-negative Rac1, Ccd42, and RhoA plasmids, which act by sequestering respective GEFs. ERK2 phosphorylation in antibody-triggered B35-L1 cells was effectively blocked by the expression of dominant-negative $\operatorname{Rac} 1(17 N)$ but not $\operatorname{RhoA}(19 \mathrm{~N})$ or Cdc42(17N) mutants (Fig. $4 B)$. C3 botulinum toxin, which inhibits RhoA, B, and $\mathrm{C}$ but not Rac or Cdc42 (Braun et al., 1989; Chrzanowska-Wodnicka and Burridge, 1996), also had no effect on L1-dependent ERK phosphorylation (Fig. 4D). The participation of Rac in L1 signaling was confirmed in an assay that directly measured the production of activated, GDP-bound Rac (Bagrodia et al., 1998). Cell lysates from L1 antibody-treated B35-L1 cells were incubated with purified RBD-GST fusion protein, which selectively binds Rac-GTP and not Rac-GDP. The amount of Rac-GTP pulled down by the RBD-GST complexes was significantly increased after L1 stimulation of B35-L1 cells (Fig. 4C). These results supported a role for Rac in L1 signaling to MAPK.

L1-triggered MAPK activation in B35-L1 neuroblastoma cells differed from NCAM140 signaling to MAPK in its independence from Ras and the focal adhesion kinase $\mathrm{p} 125^{\mathrm{fak}}$. Cotransfection of B35-L1 cells with HA-ERK2 and a dominant-negative Ras(15A) plasmid, which sequesters Ras-GEFs (Quilliam et al., 1994), had no effect on L1 antibody-stimulated ERK phosphorylation, whereas it strongly inhibited MAPK activation by EGF (Fig. 4B). Expression of a Ras dominant-negative mutant (Ras17N) or a competitive N-terminal Raf peptide that binds Ras (Brtva et al., 1995) also had no effect (data not shown). Under the same conditions, $\operatorname{Ras}(15 \mathrm{~A})$ and $\operatorname{Ras}(17 \mathrm{~N})$ interfered strongly with NCAM140-dependent MAPK activation in B35 cells (Schmid et al., 1999). In a coupled immune complex kinase assay for Rafinduced phosphorylation of MBP (Fucini et al., 1999), neither c-Raf nor B-Raf became activated to a significant degree $(>10 \%$ over the normal IgG control) during L1 antibody stimulation of B35-L1 cells. Dominant-negative Raf-1 or B-Raf mutants (S621A or R89L) also produced insignificant inhibition of ERK2 phosphorylation ( $>1.2$-fold).

Similarly, expression of FRNK (Schaller et al., 1993; Richardson and Parsons, 1996) or the autophosphorylation site mutant Fak(Y397F) (Schaller et al., 1994), which are dominant interfering inhibitors of p125 fak , did not affect L1-triggered HA-ERK2 activation (Fig. 4B), whereas under the same conditions they inhibited NCAM140-triggered MAPK activation in B35 cells (Schmid et al., 1999). Tyrosine phosphorylation of $\mathrm{p} 125^{\text {fak }}$ was also not increased after L1 antibody triggering, as assessed by Western blotting with phosphotyrosine antibodies in Fak immunoprecipitates (data not shown).

\section{pp60 ${ }^{c-s r c}$ mediates ERK phosphorylation induced by L1}

Because neuronal process extension on purified L1 is regulated by the nonreceptor tyrosine kinase pp60 ${ }^{c-s r c}$ (Ignelzi et al., 1994), we investigated whether pp $60^{c-s r c}$ played a role in MAPK activation triggered by L1. B35-L1 neuroblastoma cells were cotransfected with HA-ERK2 and the dominant-negative c-Src(K295M) plasmid, which expresses a kinase-inactive form of pp60-src because of mutation of an essential lysine residue (K295) in the ATP binding site (Twamley-Stein et al., 1993). Expression of the dominant-negative src plasmid inhibited ERK2 phosphorylation by $\sim 70 \%$ in B35-L1 neuroblastoma cells treated with L1 antibodies (Fig. 5A). Moreover, endogenous ERK2 phosphorylation in cerebellar neurons from $s r c$-minus mice was $60 \%$ lower than that in wild-type neurons (Fig. 5B). The residual ERK2 phosphorylation in $s r c$-minus neurons and B35-L1 cells expressing dominantnegative Src suggested that there may an additional L1 pathway that is pp $60^{c-s r c}$ independent, in accord with the incomplete inhibition of L1-dependent neurite outgrowth in MEK-inhibited cells and by src-minus neurons (Ignelzi et al., 1994). L1 did not form a stable complex with pp60 ${ }^{c-s r c}$, because L1 and pp60 $0^{c-s r c}$ did not coimmunoprecipitate from Brij97-detergent extracts of B35-L1 cells with or without L1 clustering (data not shown) under the same conditions in which NCAM140 coimmunoprecipitated with the Src family kinase p59 ${ }^{f y n}$ (Beggs et al., 1997). 


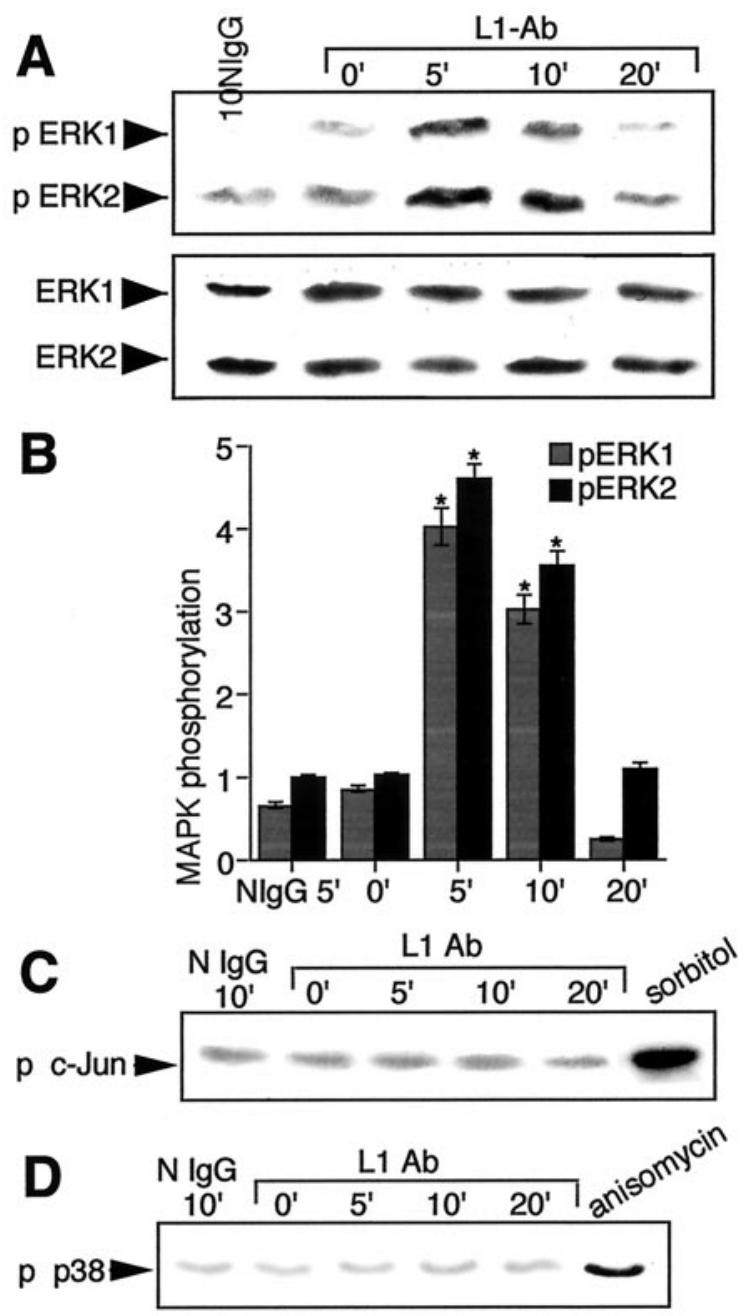

Figure 3. Clustering of L1 in B35 neuroblastoma cells transiently activates MAPK but not JNK or p38. A, Top, Rat B35 neuroblastoma cells stably expressing L1 (B35-L1) were incubated with either nonimmune mouse IgG or L1 mAb Neuro4 complexed with $\mathrm{F}\left(\mathrm{ab}^{\prime}\right)_{2}$ fragments of anti-mouse IgG for various times (5-20 min). Cell extracts were subjected to SDS-PAGE and immunoblotting with anti-active MAPK antibodies ( $p E R K 1$ and $p E R K 2)$. Bottom, The same nitrocellulose filter was stripped and reblotted with an ERK antibody recognizing ERK1 and ERK2. This experiment was repeated three times with similar kinetics and extent of MAPK activation. $B$, Densitometric quantification of MAPK phosphorylation in the experiment shown in $A$ is expressed in arbitrary units of ERK1 and ERK2 phosphorylation relative to that of the nonimmune IgG control. Error bars indicate SEs based on three experiments; an asterisk denotes statistical significance $(p<0.05)$. $C$, The same cell extracts shown in $A$ were assayed for JNK activation by the JNK immune complex kinase assay. Autoradiography showed no increase in the phosphorylation of c-Jun(1-79) by JNK from L1-stimulated cells ( $p$ c-Jun). As a positive control, cells were incubated with $300 \mathrm{~mm}$ sorbitol for $15 \mathrm{~min}$. This experiment was performed three times with similar results. $D$, The same cell extracts shown in $A$ were subjected to SDS-PAGE and immunoblotting with anti-phospho p38 MAPK antibodies, which recognize phosphorylated/activated p38 ( $p$ p38). No increase in phosphorylation levels was seen. As a positive control, cells were incubated with $10 \mathrm{~mm}$ anisomycin for $10 \mathrm{~min}$. This experiment was performed twice with similar results.

\section{pp $60^{c-s r c}$ is required for dynamin-mediated endocytosis of L1}

L1 has been shown to be endocytosed at the growth cone by a clathrin-mediated mechanism (Kamiguchi et al., 1998). To determine whether L1 endocytosis was mediated by pp60 ${ }^{\text {c-src }}$, B35-L1 cells were analyzed for L1 endocytosis by double immunofluorescence staining to visualize internalized and surface L1 with different fluorochromes. Cells were transfected with plasmids encoding wild-type Src, kinase-inactive $\operatorname{Src}(\mathrm{K} 295 \mathrm{M})$, or dominant-negative dynamin(K44A) together with a plasmid expressing cyan fluorescent protein to identify transfected cells. To induce internalization of L1, we incubated living cells for $30 \mathrm{~min}$ at $37^{\circ} \mathrm{C}$ with the monoclonal antibody Neuro4, which is directed against an extracellular epitope of L1. Cells were fixed and stained for L1 on the cell surface with rhodamine-conjugated secondary antibodies. Cells were then permeabilized and stained for internalized L1 with FITC-conjugated secondary antibodies. Confocal microscopy revealed strong FITC labeling of internalized L1 antibody complexes in a punctuate, vesicular pattern throughout the cytosol both in cyan-positive cells (Fig. 6, arrows, arrowheads) expressing wild-type Src from a transfected plasmid (Fig. 6A,E) and in nontransfected cells expressing endogenous Src (Fig. 6D,H). This observation suggested that the amount of endogenous pp $60^{c-s r c}$ was not rate-limiting for endocytosis of L1 antibody complexes in B35-L1 cells. In striking contrast, cyanpositive cells (Fig. 6, arrows, arrowheads) in cultures transfected with dominant-negative $\operatorname{Src}(\mathrm{K} 95 \mathrm{M})$ showed little L1 endocytosis (Fig. 6B,F,C,G), whereas cyan-negative cells serving as nontransfected controls within the same cultures exhibited prominent vesicular staining in the cytosol. Rhodamine staining for L1 on the cell surface appeared relatively unaltered by endocytosis, suggesting that the amount of internalized L1 was a relatively small portion of the total L1 expressed in B35-L1 cells. L1 endocytosis was not inhibited in B35-L1 cells treated with the MEK inhibitor PD98059 $(50 \mu \mathrm{M})$ (Fig. 6J,N), in cells expressing PI3-kinase $\Delta$ p85 (Fig. $6 K, O$ ), or in cells treated with the PI3kinase inhibitor Ly294002 (20 $\mu \mathrm{M})$, suggesting that PI3-kinase and MEK-MAPK did not contribute to the mechanism of endocytosis.

Dynamin GTPase plays a critical role in the formation of clathrin-coated vesicles during endocytosis of many receptors (Hinshaw and Schmid, 1995), as shown by the ability of dominantnegative dynamin(K44A) to block effectively the formation of endocytotic-coated vesicles (Damke et al., 1994). Dynamin(K44A) also prevented L1 internalization in L1-B35 cells (Fig. $6 M)$, confirming its role in internalizing L1 by a clathrinmediated mechanism (Kamiguchi et al., 1998) in B35 cells. Although Rac has been shown to modulate receptor-mediated endocytosis in some systems (Lamaze et al., 1996), expression of dominant-negative $\operatorname{Rac1}(17 \mathrm{~N})$ in B35 cells did not affect L1 antibody-induced internalization (data not shown), suggesting that this small GTPase did not regulate L1 endocytosis. Importantly, the dynamin(K44A) mutant effectively inhibited L1 antibody-induced phosphorylation of HA-ERK2 in transfected B35-L1 cells (Fig. 5A), thus indicating that an intact endocytotic mechanism was necessary for L1 triggering of the MAPK cascade.

Taken together these results demonstrated that the dynaminmediated internalization of L1 in B35-L1 cells depended on pp60 $0^{c-s r c}$ and that L1 endocytosis was required for activation of an MAPK cascade that regulated neurite outgrowth on L1.

\section{DISCUSSION}

Here we report that an MAPK-signaling pathway mediates neurite outgrowth on $\mathrm{L} 1$ and requires pp $60^{c-s r c}$-dependent endocytosis. This is the first demonstration of a neuronal function regulated by L1 via MAPK and of the role of pp $60^{c-s r c}$ in regulating 

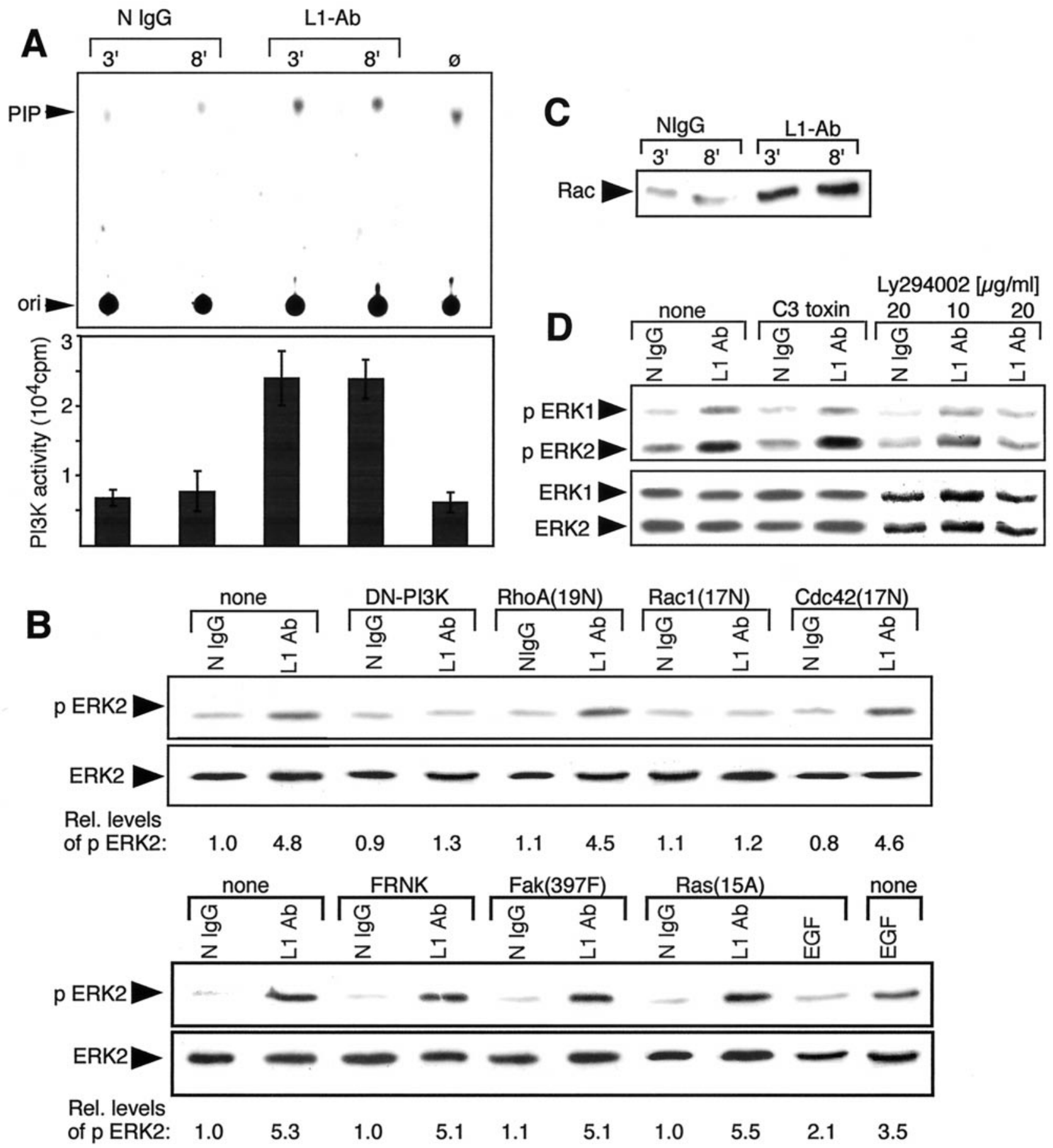

Figure 4. Dominant-negative mutants of PI3-kinase and Rac1 inhibit MAPK activation induced by L1 clustering in B35 neuroblastoma cells. $A$, B35-L1 cells were incubated with mouse $\mathrm{IgG}$ or the $\mathrm{L} 1$ monoclonal antibody Neuro4 complexed with $\mathrm{F}\left(\mathrm{ab}^{\prime}\right)_{2}$ fragments of anti-mouse IgG. Cell lysates $(800 \mu \mathrm{g})$ were immunoprecipitated with anti-phosphotyrosine $\mathrm{mAb}(4 \mathrm{G} 10)$, and the precipitates were incubated in an in vitro kinase reaction with phosphoinositides. Phospholipid products were separated by thin-layer chromatography (top). Error bars in the graph (bottom) indicate SEs based on three experiments; an asterisk denotes statistical significance $(p<0.05)$. B, Top row, B35-L1 cells transiently expressing HA-ERK2 and the dominant-negative $(D N)$ mutants PI3-kinase $(P I 3 K) \Delta \mathrm{p} 85$, RhoA(19N), Rac1(17N), Cdc42(17N), FRNK, Fak(397F), or Ras(15A) were incubated with mouse IgG or the L1 monoclonal antibody Neuro4 complexed with $\mathrm{F}\left(\mathrm{ab}^{\prime}\right)_{2}$ fragments of anti-mouse IgG. As a control, cells were exposed to $100 \mathrm{ng} / \mathrm{ml}$ EGF for 5 min. Cell extracts were immunoprecipitated with anti-HA antibodies and then subjected to SDS-PAGE and immunoblotting with anti-active MAPK antibody ( $p$ ERK2). Bottom row, The same nitrocellulose filters were stripped and reblotted with an antibody recognizing ERK2 protein. The experiments were performed three times with similar results. $C$, B35-L1 cells were incubated with normal mouse IgG or the L1 monoclonal antibody Neuro4 complexed with $\mathrm{F}\left(\mathrm{ab}^{\prime}\right)_{2}$ fragments of anti-mouse IgG for 3 and $8 \mathrm{~min}$. GTP-loaded Rac was pulled down from the cell lysates (500 $\left.\mu \mathrm{g}\right)$ by the addition of RBD-GST fusion protein conjugated to Sepharose beads, and the relative levels of Rac-GTP were evaluated by SDS-PAGE and immunoblotting with anti-Rac1 antibodies. D, Top, B35-L1 cells were exposed to the C3 toxin Rho inhibitor or the Ly294002 PI3-kinase inhibitor as described in Materials and Methods and then incubated with normal mouse IgG or the L1 monoclonal antibody Neuro4 complexed with $\mathrm{F}\left(\mathrm{ab}^{\prime}\right)_{2}$ fragments of anti-mouse IgG for 7 min. Cell extracts were subjected to SDS-PAGE and immunoblotting with anti-active MAPK antibody ( $p$ ERK2). Bottom, The same nitrocellulose filters were stripped and reblotted with an antibody recognizing ERK2 protein. ori, Origin; Rel, relative. 

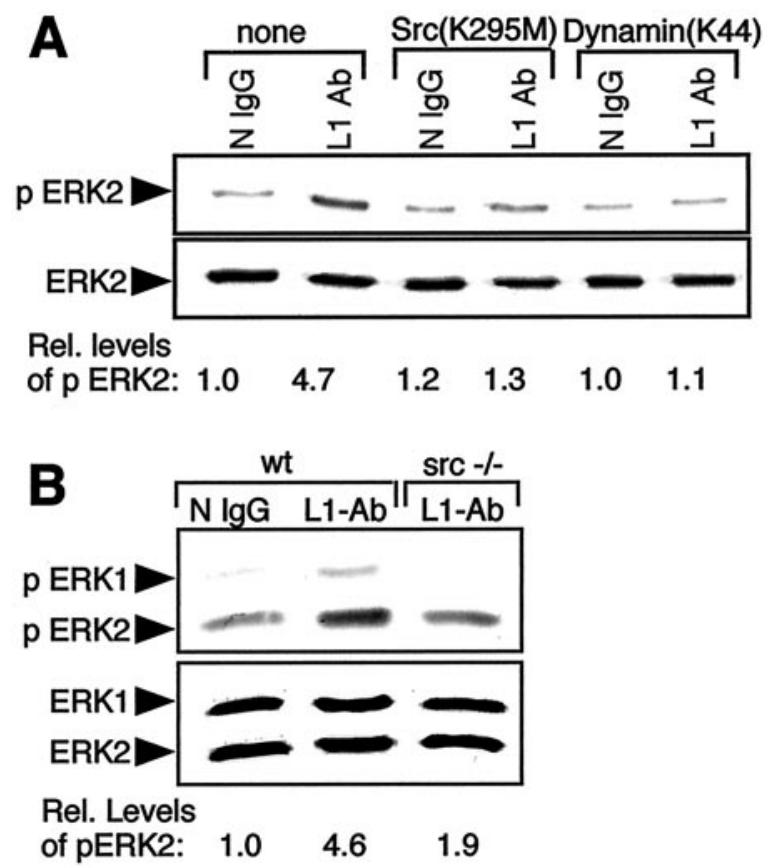

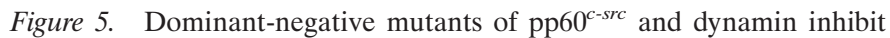
MAPK activation induced by L1 clustering in B35 neuroblastoma cells. $A$, Top, B35-L1 cells transiently expressing HA-ERK2 and the dominantnegative mutants c-Src(K295M) or dynamin (K44A) were incubated for 7 min with mouse IgG or the L1 monoclonal antibody Neuro4 complexed with $\mathrm{F}\left(\mathrm{ab}^{\prime}\right)_{2}$ fragments of anti-mouse IgG. Cell extracts in NP-40 lysis buffer were immunoprecipitated with anti-HA antibodies and then subjected to SDS-PAGE and immunoblotting with anti-active MAPK antibody ( $p$ ERK2). Bottom, The same nitrocellulose filters were stripped and reblotted with an ERK antibody recognizing ERK2 protein. The experiments were performed twice with similar results. B, Top, Cerebellar neurons from wild-type mice ( $w t)$ or $s r c$-minus mice $(s r c-/-)$ were incubated with mouse IgG or the L1 monoclonal antibody Neuro4 complexed with $\mathrm{F}\left(\mathrm{ab}^{\prime}\right)_{2}$ fragments of anti-mouse IgG. Buffers of the cell extracts were subjected to SDS-PAGE and immunoblotting with antiactive MAPK Ab ( $p$ ERK2). Bottom, The same nitrocellulose filters were stripped and reblotted with an ERK antibody recognizing ERK2. The experiments were performed twice with similar results.

dynamin-mediated endocytosis of L1 as an essential initial step in MAPK activation. Key intermediates on the L1-MAPKsignaling pathway were identified to be the small GTPase Rac and PI3-kinase. Because ERKs activate gene expression via phosphorylation of the transcription factors Elk-1 (Marais et al., 1993) and CRE-binding protein (Ginty et al., 1994), these results raise the possibility that neurite outgrowth may rely on signaling events in the growth cone and nucleus. The proposed signaling pathway is outlined in Figure 7.

Results of this study demonstrate the requirement of an intact MEK-ERK pathway in regulating neurite outgrowth by cerebellar neurons on an L1 substrate. ERK phosphorylation is widely used for neurite outgrowth in response to pleiotropic axon growth/guidance cues, which include L1m NCAM (Schmid et al., 1999), the extracellular matrix (Ihara et al., 1997), and neurotrophins (Xia et al., 1995; Riccio et al., 1997). L1 signaling to MAPK may also function in synaptic plasticity as suggested from antibody perturbation experiments (Luthi et al., 1994), because ERKs are phosphorylated in neurons during $\beta$-adrenergic and serotonergic stimulation (Koch et al., 1994; Michael et al., 1998) and in hippocampal long-term potentiation (LTP) (English and Sweatt, 1997). The extent of ERK phosphorylation triggered by
L1 (four- to fivefold) approximated that induced by NCAM (Schmid et al., 1999), NGF (Riccio et al., 1997), integrins (Chen et al., 1994), and LTP (English and Sweatt, 1997), underscoring its potential physiological relevance. By transducing signals that converge within the MAPK pathway, adhesion molecules, growth factors, and neurotransmitters may coordinately regulate the growth or branching of axons and dendrites. While our work was in progress MAPK was shown to be activated in L1-transfected NIH3T3 cells dependent on endocytosis (Schaefer et al., 1999). Our studies in neural cells are in accord with this report but go further by demonstrating a physiological role for MAPK in L1dependent neurite outgrowth and by identifying pp60 6 -src Rac, and PI3-kinase as key signaling intermediates in the pathway.

An important finding of our work is the requirement for pp $60^{c-s r c}$ in dynamin-dependent endocytosis of L1 and activation of MAPKs in neural cells. These results provide a mechanistic understanding of the inhibition of L1-dependent neurite outgrowth observed in $s r c$-minus neuronal cultures (Ignelzi et al., 1994). Our studies suggest (1) that pp60-src acts as a gatekeeper of the MAPK cascade by regulating L1 endocytosis and (2) that endocytosis and MAPK activation are needed for neurite growth on L1. Dynamin-mediated endocytosis is also an early step in MAPK activation induced by EGF (Vieira et al., 1996), serotonin 5-HT1A (Della Rocca et al., 1999), insulin-like growth factor I (Chow et al., 1998), lysophosphatidic acid (Luttrell et al., 1997), and $\beta_{2}$-adrenergic agonists (Daaka et al., 1998). Although only L1 and the $\beta_{2}$-adrenergic receptor have been shown to depend on pp $60^{c-s r c}$ for endocytosis and MAPK activation (Ahn et al., 1999), it is conceivable that Src family kinases may participate in endocytosis/signaling by other receptors. It remains to be determined whether L1 clustering activates pp60-src by dephosphorylating Tyr 527 in the Src C-terminal domain (Bjorge et al., 1996) possibly via tyrosine phosphatase PTP- $\alpha$ (Ponniah et al., 1999). A role for tyrosine phosphatases in L1 signaling is consistent with the ability of L1 antibodies to induce dephosphorylation of tyrosine in growth cone proteins (Atashi et al., 1992; Klinz et al., 1995). Because neurite outgrowth by cerebellar neurons on L1 was not totally suppressed by MEK inhibitors or in src-minus neurons (Ignelzi et al., 1994), there may be an additional Src/ MAPK-independent mechanism for L1-dependent neurite growth. For example, neurite growth responses in common to L1, NCAM, and N-cadherin have been shown to occur via the basic fibroblast growth factor receptor, phospholipase C, and production of arachidonic acid (Saffell et al., 1997). It should be noted that because different cell types (cerebellar neurons and B35 neuroblastoma cells) were used to measure neurite outgrowth and endocytosis, the results do not formally prove that endocytosis of L1 is required for the regulation of neurite outgrowth. Other than pp60 6 -src it is not clear whether components of the L1-MAPK cascade identified in B35 cells are also deployed for signal transduction and neurite outgrowth in cerebellar neurons and other neuronal cell types. Nonetheless, the finding that pp $60^{c-s r c}$ was needed for ERK activation in both cell types and that deletion of the src gene causes inhibition of neurite outgrowth in cerebellar neurons (Ignelzi et al., 1994) supports the possibility that Src-dependent endocytosis mediates neurite outgrowth on L1.

L1 signaling, as delineated in B35 cells, differed from the prototypical Ras-MAPK cascade used by NCAM and integrins (Schlaepfer and Hunter, 1997; Schmid et al., 1999) in its independence from Ras and Fak. However, Ras-independent (Howe and Juliano, 1998) and FAK-independent signaling pathways are 

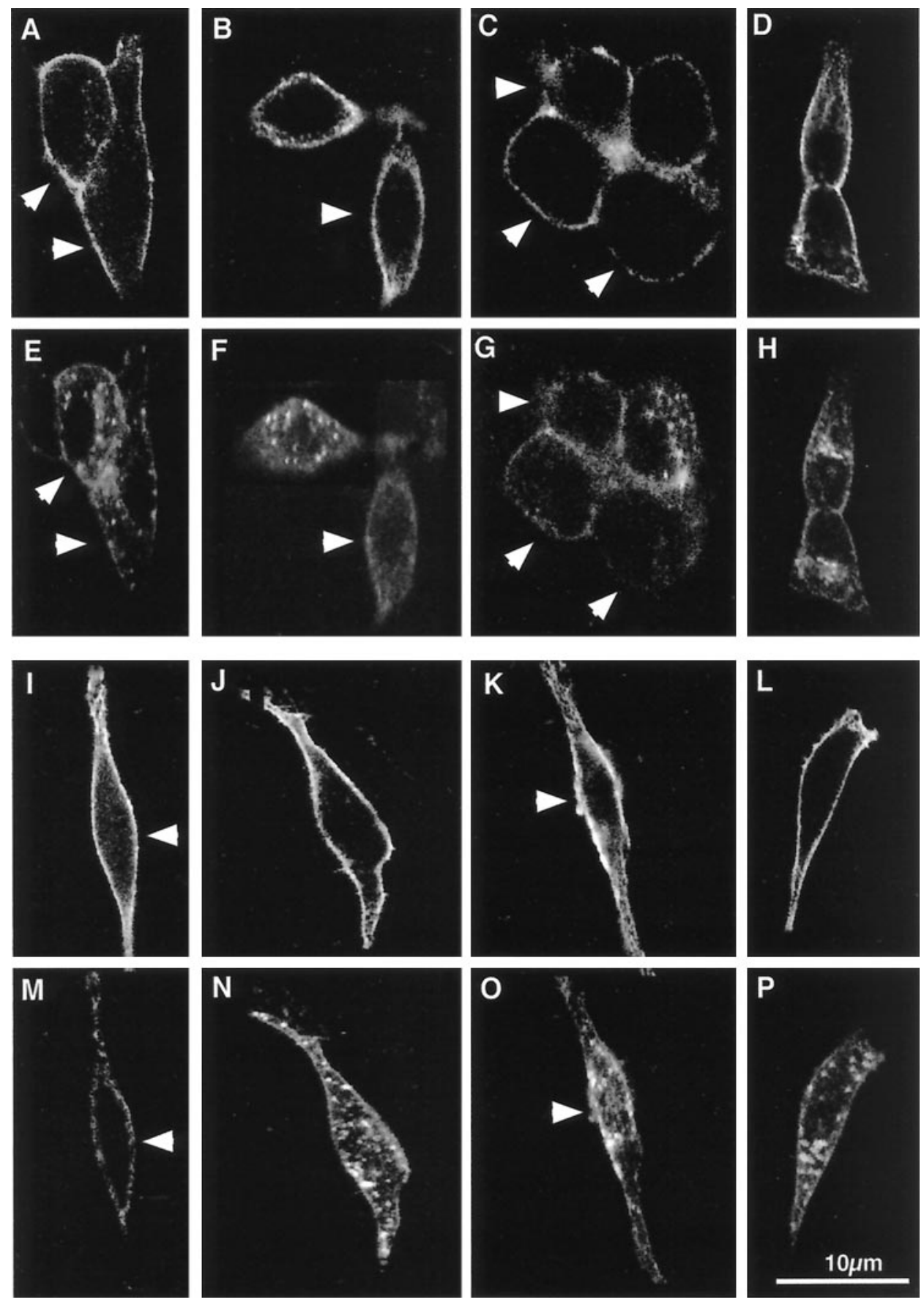
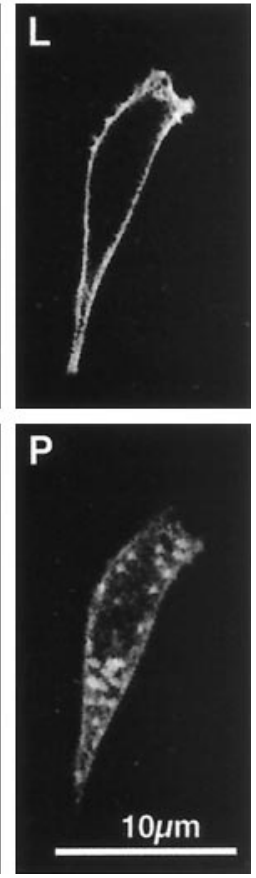

Figure 6. Endocytosis of L1 antibody complexes requires pp $60^{c-s r c}$ and dynamin. Endocytosis of L1 antibody complexes induced with Neuro4 monoclonal antibodies against an extracellular epitope of L1 was visualized in transfected B35-L1 neuroblastoma cells by double immunofluorescence staining for L1 on the cell surface (rhodamine) and internalized L1 (FITC) using confocal microscopy as described in Materials and Methods. B35-L1 cells were cotransfected with one of the pcDNA3 plasmids listed below together with equimolar amounts of a plasmid expressing enhanced cyan fluorescent protein (ECFP) as a marker for transfected cells. Arrows and arrowheads denote ECFP-positive cells. Images show representative cells from all experiments. $A, E$, Wild-type c-Src. $B, F, C, G$, Dominantnegative $\operatorname{Src}(\mathrm{K} 295 \mathrm{M})$. $D, H$, No transfection. $I, M$, Dominant-negative dynamin(K44A). $J, \quad N$, Treatment with MEK inhibitor PD98059 $(50 \mu \mathrm{M}) . \quad K, \quad O$, Dominant-negative PI3-kinase $(\Delta \mathrm{p} 85)$. $L$, $P$, Treatment with PI3-kinase inhibitor Ly294002 $(20 \mu \mathrm{M}) . A-D$ and $I-L$ show L1 on the cell surface (rhodamine); $E-H$ and $M-P$ show internalized L1 (FITC). Scale bar, $10 \mu \mathrm{m}$. used for some forms of integrin signaling (Lin et al., 1997; Miranti et al., 1998). FAK-independent signaling in platelets shares with the L1 pathway the involvement of pp60 ${ }^{c-s r c}$, Rac, and PI3-kinase (Miranti et al., 1998). Although we have not found $\beta 1$-integrins stably associated with L1, a role for specific $\beta$-integrin subtypes in L1-MAPK signaling remains open, because L1 has been shown to interact functionally with integrins for neurite outgrowth and cell migration on L1, mediated in part by an RGD sequence in the sixth Ig domain (Montgomery et al., 1996; Yip et al., 1998).

Neuronal growth cones display distinctive morphologies on L1, NCAM, and laminin (Payne et al., 1992; Abosch and Lagenaur, 1993; Burden-Gulley et al., 1995, 1997); yet each substrate can activate MAPKs, raising the question of how specificity arises.
Activation of different signaling intermediates on the MAPK pathway may allow neurons to respond to extracellular cues in distinct ways. In B35 cells, L1 signals to MAPK via pp60 ${ }^{c-s r c}$, PI3-kinase, and Rac, whereas NCAM140 signals to MAPK via Fyn, FAK, Ras, and Rho (Schmid et al., 1999). Nonetheless, the involvement of Rac in L1 signaling is consistent with the lamellipodial morphology displayed by growth cones of retinal ganglion cells on L1 (Payne et al., 1992; Burden-Gulley et al., 1995). Activated Rho family GTPases differentially modulate actin cytoarchitecture (Nobes and Hall, 1995). Rac generates lamellipodia by inducing actin depolymerization via LIM kinase-1 (Arber et al., 1998; Yang et al., 1998), Rho induces actin stress fibers and growth cone collapse (Kozma et al., 1997), and Cdc42 elicits filopodia via LIM kinase-2 (Sumi et al., 1999). PI3-kinase may 


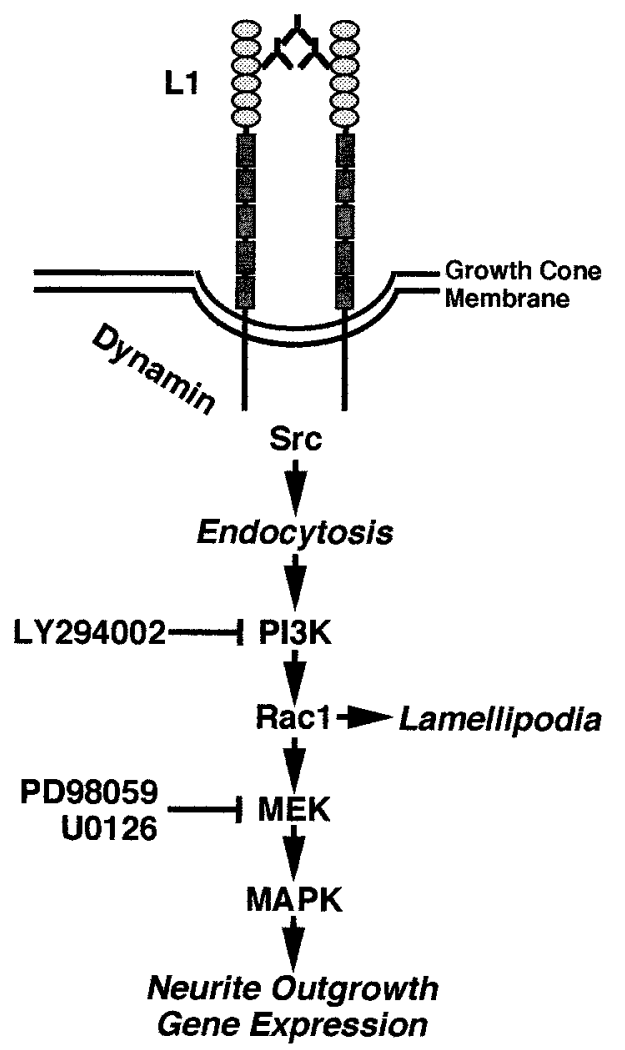

Figure 7. Proposed L1-signaling pathway. Cross-linking of L1 molecules on the growth cone membrane is proposed to induce dynamin-mediated endocytosis of L1 via the Src tyrosine kinase, leading to initiation of an intracellular signal transduction cascade involving the sequential activation of PI3-kinase, Rac, MEK, and MAPK. Inhibitors of PI3-kinase (Ly294002) and MEK (PD98059 and U0126) are shown. It is suggested that Rac activation in the growth cone leads to cytoskeletal changes resulting in lamellipodia and that MAPK may have nuclear effects on gene expression, both of which may be needed for neurite outgrowth.

promote Rac activation via the binding of phosphoinositide products to the plextrin homology domain of Rac-GEFs (Han et al., 1998; Nimnual et al., 1998). PI3-kinase is an important determinant of growth cone guidance, required for the turning of Xenopus growth cones toward a netrin gradient (Hong et al., 1999).

The ability of L1 to phosphorylate ERKs via Rac could occur by cross-cascade stimulation of MEK. Rac typically activates the JNK pathway (Crespo et al., 1996) but is an upstream regulator of p21-activated kinase, which directly phosphorylates MEK and stimulates ERK phosphorylation in a Ras-independent manner (Frost et al., 1997). Such cross-talk allows pathways for Rac activation to cooperate with prototypical Ras-Raf-MEKMAPK pathways (Frost et al., 1997). In this way, NCAM or neurotrophin signaling via Ras may cooperate with L1 signaling via Rac for MAPK activation and neurite outgrowth. Although we found no evidence of c-Raf 1 or B-Raf in L1 signaling, basal levels of a Raf isoform might participate.

The ability of L1 clustering to activate PI3-kinase also supports a role for L1 in neuronal survival. PI3-kinase promotes neuronal survival and blocks apoptosis in response to neurotrophins and insulin-like growth factor I via the serine/threonine kinase Akt (Ashcroft et al., 1999). Although Akt was not examined in our studies, a role for L1 in neuronal survival is consistent with a $30 \%$ reduction in the number of hippocampal neurons in L1 knock-out mice (Demyanenko et al., 1999) and with the ability of L1 to enhance the survival of dopaminergic neurons (Hulley et al., 1998) and to prevent apoptotic death of cerebellar and hippocampal neurons in culture (Chen et al., 1999).

Src-mediated endocytosis of L1 has the potential for not only local actin cytoskeletal rearrangements in the growth cone but also nuclear transcriptional control. Via Rac and PI3-kinase, L1 could cause actin rearrangements to form lamellipodial extensions needed for neurite elongation. Endocytosis of L1 might also serve to release the growth cone from attachment to the substratum, facilitating its forward migration. L1 in endocytic vesicles would be oriented with its $\mathrm{C}$ terminal projecting toward the cytoplasm, enabling downstream signaling molecules in the growth cone to be recruited and/or activated, a scenario consistent with the observation that activated ERK colocalizes with L1 in endocytosed vesicles of L1-transfected fibroblasts (Schaefer et al., 1999). L1-signaling complexes might also be transported from the growth cone to the cell body, as shown for internalized NGF-Trk receptor complexes in pheochromocytoma 12 cells (Riccio et al., 1997). There dually phosphorylated ERKs would be in position to translocate into the nucleus, where they may induce transcription of the genes needed for neuronal process extension or cell survival.

\section{REFERENCES}

Abosch A, Lagenaur C (1993) Sensitivity of neurite outgrowth to microfilament disruption varies with adhesion molecule substrate. J Neurobiol 24:344-355.

Ahn S, Maudsley S, Luttrell LM, Lefkowitz RJ, Daaka Y (1999) Srcmediated tyrosine phosphorylation of dynamin is required for beta2adrenergic receptor internalization and mitogen-activated protein kinase signaling. J Biol Chem 274:1185-1188.

Alessi DR, Cuenda A, Cohen P, Dudley DT, Saltiel AR (1995) PD 098059 is a specific inhibitor of the activation of mitogen-activated protein kinase kinase in vitro and in vivo. $\mathrm{J}$ Biol Chem 270:27489-27494.

Appel F, Holm J, Conscience J-F, Schachner M (1993) Several extracellular domains of the neural cell adhesion molecule L1 are involved in neurite outgrowth and cell body adhesion. J Neurosci 13:4764-4775.

Arber S, Barbayannis FA, Hanser H, Schneider C, Stanyon CA, Bernard O, Caroni P (1998) Regulation of actin dynamics through phosphorylation of cofilin by LIM-kinase. Nature 393:805-809.

Ashcroft M, Stephens RM, Hallberg B, Downward J, Kaplan DR (1999) The selective and inducible activation of endogenous PI 3-kinase in PC12 cells results in efficient NGF-mediated survival but defective neurite outgrowth. Oncogene 18:4586-4597.

Atashi JR, Klinz SG, Ingraham CA, Matten WT, Schachner M, Maness PF (1992) Neural cell adhesion molecules modulate tyrosine phosphorylation of tubulin in nerve growth cone membranes. Neuron $8: 1-20$.

Bagrodia S, Taylor SJ, Jordon KA, Van Aelst L, Cerione RA (1998) A novel regulator of p21-activated kinases. J Biol Chem 273:23633-23636.

Beggs HE, Baragona SC, Hemperly JJ, Maness PF (1997) NCAM-140 interacts with the focal adhesion kinase $\mathrm{p} 125^{\text {fak }}$ and the src-related tyrosine kinase p59 fyn J Biol Chem 272:8310-8319.

Bjorge JD, O'Connor TJ, Fujita DJ (1996) Activation of human pp60csrc. Biochem Cell Biol 74:477-484.

Braun U, Habermann B, Just I, Aktories K, Vandekerckhove J (1989) Purification of the $22 \mathrm{kDa}$ protein substrate of botulinum ADPribosyltransferase C3 from porcine brain cytosol and its characterization as a GTP-binding protein highly homologous to the rho gene product. FEBS Lett 243:70-76.

Brtva TR, Drugan JK, Ghosh S, Terrell RS, Campbell-Burk S, Bell RM, Der CJ (1995) Two distinct Raf domains mediate interaction with Ras. J Biol Chem 270:9809-9812.

Burden-Gulley SM, Payne HR, Lemmon V (1995) Growth cones are actively influenced by substrate-bound adhesion molecules. J Neurosci 15:4370-4381.

Burden-Gulley SM, Pendergast M, Lemmon V (1997) The role of cell adhesion molecule L1 in axonal extension, growth cone motility, and signal transduction. Cell Tissue Res 290:415-422. 
Chen Q, Kinch MS, Lin TH, Burridge K, Juliano RL (1994) Integrinmediated cell adhesion activates mitogen-activated protein kinases. J Biol Chem 269:26602-26605.

Chen S, Mantei N, Dong L, Schachner M (1999) Prevention of neuronal cell death by neural adhesion molecules L1 and CHL1. J Neurobiol 38:428-439.

Chow JC, Condorelli G, Smith RJ (1998) Insulin-like growth factor-I receptor internalization regulates signaling via the Shc/mitogenactivated protein kinase pathway, but not the insulin receptor substrate-1 pathway. J Biol Chem 273:4672-4680.

Chrzanowska-Wodnicka M, Burridge K (1996) Rho-stimulated contractility drives the formation of stress fibers and focal adhesions. J Cell Biol 133:1403-1415.

Cohen NR, Taylor JSH, Scott LB, Guillery RW, Soriano P, Furley AJW (1997) Errors in corticospinal axon guidance in mice lacking the neural cell adhesion molecule L1. Curr Biol 8:26-33.

Conricode KM (1995) Involvement of phosphatidylinositol 3-kinase in stimulation of glucose transport by growth factors in 3T3-L1 adipocytes. Biochem Mol Biol Int 36:835-843.

Crespo P, Bustelo XR, Aaronson DS, Coso OA, Lopez-Barahona M, Barbacid M, Gutkind JS (1996) Rac-1 dependent stimulation of the JNK/SAPK signaling pathway by Vav. Oncogene 13:455-460.

Crews CM, Alessandrini A, Erikson RL (1992) The primary structure of MEK, a protein kinase that phosphorylates the ERK gene product. Science 258:478-480.

Cross DA, Watt PW, Shaw M, van der Kaay J, Downes CP, Holder JC, Cohen P (1997) Insulin activates protein kinase B, inhibits glycogen synthase kinase-3 and activates glycogen synthase by rapamycininsensitive pathways in skeletal muscle and adipose tissue. FEBS Lett 406:211-215.

Daaka Y, Luttrell LM, Ahn S, Della Rocca GJ, Ferguson SS, Caron MG, Lefkowitz RJ (1998) Essential role for G protein-coupled receptor endocytosis in the activation of mitogen-activated protein kinase. J Biol Chem 273:685-688.

Dahlin-Huppe K, Berglund EO, Ranscht B, Stallcup WB (1997) Mutational analysis of the L1 neuronal cell adhesion molecule identifies membrane-proximal amino acids of the cytoplasmic domain that are required for cytoskeletal anchorage. Mol Cell Neurosci 9:144-156.

Dahme M, Bartsch U, Martini R, Anliker B, Schachner M, Mantei N (1997) Disruption of the mouse L1 gene leads to malformations of the nervous system. Nat Genet 17:346-349.

Damke H, Baba T, Warnock DE, Schmid SL (1994) Induction of mutant dynamin specifically blocks endocytic coated vesicle formation. J Cell Biol 127:915-934.

Davis JQ, Bennett V (1994) Ankyrin binding activity shared by the neurofascin/L1/NrCAM family of cell adhesion molecules. J Biol Chem 269:27163-27166.

Della Rocca GJ, Mukhin YV, Garnovskaya MN, Daaka Y, Clark GJ, Luttrell LM, Lefkowitz RJ, Raymond JR (1999) Serotonin 5-HT1A receptor-mediated Erk activation requires calcium/calmodulindependent receptor endocytosis. J Biol Chem 274:4749-4753.

Demyanenko G, Tsai A, Maness PF (1999) Abnormalities in neuronal process extension, hippocampal development, and the ventricular system of L1 knockout mice. J Neurosci 19:4907-4920.

English JD, Sweatt JD (1996) Activation of p42 mitogen-activated protein kinase in hippocampal long term potentiation. J Biol Chem 271:24329-24332.

English JD, Sweatt JD (1997) A requirement for the mitogen-activated protein kinase cascade in hippocampal long term potentiation. J Biol Chem 272:19103-19106.

Favata MF, Horiuchi KY, Manos EJ, Daulerio AJ, Stradley DA, Feeser WS, Van Dyk DE, Pitts WJ, Earl RA, Hobbs F, Copeland RA, Magolda RL, Scherle PA, Trzaskos JM (1998) Identification of a novel inhibitor of mitogen-activated protein kinase kinase. J Biol Chem 273:18623-18632.

Fransen E, VanCamp G, Vits L, Willems PJ (1997) L1-associated diseases: clinical geneticists divide, molecular geneticists unite. Hum Mol Genet 6:1625-1632.

Frost JA, Steen H, Shapiro P, Lewis T, Ahn N, Shaw PE, Cobb MH (1997) Cross-cascade activation of ERKs and ternary complex factors by Rho family proteins. EMBO J 16:6426-6438.

Fucini RV, Okada S, Pessin JE (1999) Insulin-induced desensitization of extracellular signal-regulated kinase activation results from an inhibition of Raf activity independent of Ras activation and dissociation of the Grb2-SOS complex. J Biol Chem 274:18651-18658.
Fuller SJ, Davies EL, Gillespie-Brown J, Sun H, Tonks NK (1997) Mitogen-activated protein kinase phosphatase 1 inhibits the stimulation of gene expression by hypertrophic agonists in cardiac myocytes. Biochem J 323:313-319.

Ginty DD, Bonni A, Greenberg ME (1994) Nerve growth factor activates a Ras-dependent protein kinase that stimulates c-fos transcription via phosphorylation of CREB. Cell 77:713-725.

Han J, Luby-Phelps K, Das B, Shu X, Xia Y, Mosteller RD, Krishna UM, Falck JR, White MA, Broek D (1998) Role of substrates and products of PI 3-kinase in regulating activation of Rac-related guanosine triphosphatases by Vav. Science 279:558-560.

Haney CA, Sahenk Z, Li C, Lemmon VP, Roder J, Trapp BD (1999) Heterophilic binding of L1 on unmyelinated sensory axons mediates Schwann cell adhesion and is required for axonal survival. J Cell Biol 146:1173-1184.

Hara K, Yonezawa K, Sakaue H, Ando A, Kotani K, Kitamura T, Kitamura Y, Ueda H, Stephens L, Jackson TR, Waterfield MD, Kaskga M (1994) 1-Phosphatidylinositol 3-kinase activity is required for insulin-stimulated glucose transport but not for RAS activation in CHO cells. Proc Natl Acad Sci USA 91:7415-7419.

Heldin CH (1995) Dimerization of cell surface receptors in signal transduction. Cell 80:213-223.

Hinshaw JE, Schmid SL (1995) Dynamin self-assembles into rings suggesting a mechanism for coated vesicle budding. Nature 374:190-192.

Hong K, Hinck L, Nishiyama M, Poo MM, Tessier-Lavigne M, Stein E (1999) A ligand-gated association between cytoplasmic domains of UNC5 and DCC family receptors converts netrin-induced growth cone attraction to repulsion. Cell 97:927-941.

Howe AK, Juliano RL (1998) Distinct mechanisms mediate the initial and sustained phases of integrin-mediated activation of the Raf/MEK/ mitogen-activated protein kinase cascade. J Biol Chem 273:27268-27274.

Hulley P, Schachner M, Lubbert H (1998) L1 neural cell adhesion molecule is a survival factor for fetal dopaminergic neurons. J Neurosci Res 53:129-134.

Ignelzi MA, Miller DR, Soriano P, Maness PF (1994) Impaired neurite outgrowth of src-minus cerebellar neurons on the cell adhesion molecule L1. Neuron 12:873-884.

Ihara S, Nakajima K, Fukada T, Hibi M, Ngata S, Hirano T, Fukui Y (1997) Dual control of neurite outgrowth by STAT3 and MAP kinase in PC12 cells stimulated by interleukin-6. EMBO J 16:5345-5352.

Kamiguchi H, Lemmon V (1998) A neuronal form of the cell adhesion molecule L1 contains a tyrosine-based signal required for sorting to the axonal growth cone. J Neurosci 18:3749-3756.

Kamiguchi H, Long KE, Pendergast M, Schaefer AW, Rapoport I, Kirchhausen T, Lemmon V (1998) The neural cell adhesion molecule L1 interacts with the AP-2 adaptor and is endocytosed via the clathrinmediated pathway. J Neurosci 18:5311-5321.

Klinz SG, Schachner M, Maness PF (1995) L1 and NCAM antibodies trigger protein phosphatase activity in growth cone-enriched membranes. J Neurochem 65:84-95.

Koch WJ, Hawes BE, Allen LF, Lefkowitz RJ (1994) Direct evidence that Gi-coupled receptor stimulation of mitogen-activated protein kinase is mediated by $\mathrm{G}$ beta gamma activation of p21ras. Proc Natl Acad Sci USA 91:12706-12710.

Kozma R, Sarner S, Ahmed S, Lim L (1997) Rho family GTPases and neuronal growth cone remodelling: relationship between increased complexity induced by $\mathrm{Cdc} 42 \mathrm{Hs}$, Rac1, and acetylcholine and collapse induced by RhoA and lysophosphatidic acid. Mol Cell Biol 17:1201-1211.

Lamaze C, Chuang TH, Terlecky LJ, Bokoch GM, Schmid SL (1996) Regulation of receptor-mediated endocytosis by Rho and Rac. Nature 382:177-179.

Lin TH, Aplin AE, Shen Y, Chen Q, Schaller M, Romer L, Aukhil I, Juliano RL (1997) Integrin-mediated activation of MAP kinase is independent of FAK: evidence for dual integrin signaling pathways in fibroblasts. J Cell Biol 136:1385-1395.

Luthi A, Laurent JP, Figurov A, Muller D, Schachner M (1994) Hippocampal long-term potentiation and neural cell adhesion molecules L1 and NCAM. Nature 372:777-779.

Luttrell LM, Daaka Y, Della Rocca GJ, Lefkowitz RJ (1997) G proteincoupled receptors mediate two functionally distinct pathways of tyrosine phosphorylation in rat 1a fibroblasts. She phosphorylation and receptor endocytosis correlate with activation of Erk kinases. J Biol Chem 272:31648-31656.

Madhani HD, Styles CA, Fink GR (1997) MAP kinases with distinct 
inhibitory functions impart signaling specificity during yeast differentiation. Cell 91:673-684.

Maness PF, Beggs HE, Klinz SG, Morse WR (1996) Selective neural cell adhesion molecule signaling by $\operatorname{src}$ family tyrosine kinases and phosphatases. Perspect Dev Neurobiol 4:169-181.

Marais R, Wynne J, Treisman R (1993) The SRF accessory protein Elk-1 contains a growth factor-regulated transcriptional activation domain. Cell 73:381-393.

Marshall CJ (1994) MAP kinase kinase kinase, MAP kinase kinase and MAP kinase. Curr Opin Genet Dev 4:82-89.

Michael D, Martin KC, Seger R, Ning MM, Baston R, Kandel ER (1998) Repeated pulses of serotonin required for long-term facilitation activate mitogen-activated protein kinase in sensory neurons of Aplysia. Proc Natl Acad Sci USA 95:1864-1869.

Miranti CK, Leng L, Maschberger P, Brugge JS, Shattil SJ (1998) Identification of a novel integrin signaling pathway involving the kinase Syk and the guanine nucleotide exchange factor Vav1. Curr Biol 8:1289-1299.

Montgomery AMP, Becker JC, Siu C, Lemmon VP, Cheresh DA, Pancook JD, Zhao X, Reisfeld RA (1996) Human neural cell adhesion molecule L1 and rat homologue NILE are ligands for integrin_v_3. J Cell Biol 132:475-485.

Myers Jr MG, Sun XJ, Cheatham B, Jachna BR, Glasheen EM, Backer JM, White MF (1993) IRS-1 is a common element in insulin and insulin-like growth factor-I signaling to the phosphatidylinositol $3^{\prime}$ kinase. Endocrinology 132:1421-1430.

Nave BT, Siddle K, Shepherd PR (1996) Phorbol esters stimulate phosphatidylinositol 3,4,5-trisphosphate production in 3T3-L1 adipocytes: implications for stimulation of glucose transport. Biochem $\mathrm{J}$ 318:203-205.

Nimnual AS, Yatsula BA, Bar-Sagi D (1998) Coupling of Ras and Rac guanosine triphosphatases through the Ras exchanger Sos. Science 279:560-563.

Nobes CD, Hall A (1995) Rho, rac and cdc42 GTPases: regulators of actin structures, cell adhesion and motility. Biochem Soc Trans 23:456-459.

Payne HR, Burden SM, Lemmon V (1992) Modulation of growth cone morphology by substrate-bound adhesion molecules. Cell Motil Cytoskeleton 21:65-73.

Persohn E, Schachner M (1990) Immunohistological localization of the neural cell adhesion molecule L1 and NCAM in the developing hippocampus of the mouse. J Neurocytol 19:807-819.

Ponniah S, Wang DZ, Lim KL, Pallen CJ (1999) Targeted disruption of the tyrosine phosphatase PTPalpha leads to constitutive downregulation of the kinases Src and Fyn. Curr Biol 9:535-538.

Quilliam LA, Kato K, Rabun KM, Hisaka MM, Huff SY, Campbell-Burk S, Der CJ (1994) Identification of residues critical for Ras(17N) growth-inhibitory phenotype and for Ras interaction with guanine nucleotide exchange factors. Mol Cell Biol 14:1113-1121.

Quilliam LA, Khosravi-Far R, Huff SY, Der CJ (1995) Guanine nucleotide exchange factors: activators of the Ras superfamily of proteins. BioEssays 17:395-404.

Riccio A, Pierchala BA, Ciarallom CL, Ginty DD (1997) An NGFTrkA-mediated retrograde signal to transcription factor CREB in sympathetic neurons. Science 277:1097-1100.

Richardson A, Parsons T (1996) A mechanism for regulation of the adhesion-associated protein tyrosine kinase pp125FAK. Nature 380:538-540.

Ridley AJ, Paterson HF, Johnston CL, Diekmann D, Hall A (1992) The small GTP-binding protein rac regulates growth factor-induced membrane ruffling. Cell 70:401-410.

Saffell JL, Williams EJ, Mason IJ, Walsh FS, Doherty P (1997) Expression of a dominant negative FGF receptor inhibits axonal growth and FGF receptor phosphorylation stimulated by CAMs. Neuron 18:231-242.

Schaefer AW, Kamiguchi H, Wong EV, Beach CM, Landreth G, Lemmon V (1999) Activation of the MAPK signal cascade by the neural cell adhesion molecule L1 requires L1 internalization. J Biol Chem 274:37965-37973.

Schaller MD, Borgman CA, Parsons JT (1993) Autonomous expression of a noncatalytic domain of the focal adhesion-associated protein tyrosine kinase pp125FAK. Mol Cell Biol 13:785-791.

Schaller MD, Hildebrand JD, Shannon JD, Fox JW, Vines RR, Parsons JT (1994) Autophosphorylation of the focal adhesion kinase, pp125 ${ }^{\mathrm{FAK}}$, directs SH2-dependent binding of $\mathrm{pp} 60^{\mathrm{src}}$. Mol Cell Biol 14:1680-1688.

Schlaepfer DD, Hunter T (1997) Focal adhesion kinase overexpression enhances ras-dependent integrin signaling to ERK2/mitogen-activated protein kinase through interaction with and activation of c-Src. J Biol Chem 272:13189-13195.

Schmid R-S, Maness PF (2000) Cell recognition molecules and disorders of neurodevelopment. In: International handbook on brain and behaviour in human development (Kalverboer AF, Gramsbergen A, eds). Groningen, The Netherlands: Academic, in press.

Schmid R-S, Hemperly JJ, Schaller MD, Maness PF (1997) NCAM and L1 cell adhesion molecules activate MAP kinase signaling pathways. Soc Neurosci Abstr 23:767.6.

Schmid R-S, Graff R, Schaller MD, Chen S, Schachner M, Hemprily JJ, Maness PF (1999) NCAM stimulates the Ras-MAPK pathway and CREB phosphorylation in neuronal cells. J Neurobiol 38:542-555.

Schnitzer J, Schachner M (1981) Characterization of isolated mouse cerebellar cell populations in vitro. J Neuroimmunol 1:457-470.

Scholey AB, Rose SP, Zamani MR, Bock E, Schachner M (1993) A role for the neural cell adhesion molecule in a late, consolidating phase of glycoprotein synthesis six hours following passive avoidance training of the young chick. Neuroscience 55:499-509.

Schubert D, Heinemann S, Carlisle W, Tarikas H, Kimes B, Patrick J, Steinback JH, Culp W, Brandt BL (1974) Clonal cell lines from the rat central nervous system. Nature 249:224-227.

Schuch U, Lohse MJ, Schachner M (1989) Neural cell adhesion molecules influence second messenger systems. Neuron 3:13-20.

Sumi T, Matsumoto K, Takai Y, Nakamura T (1999) Cofilin phosphorylation and actin cytoskeletal dynamics regulated by Rho- and Cdc42activated LIM-kinase 2. J Cell Biol 147:1519-1532.

Twamley-Stein GM, Pepperkok R, Ansorge W, Courtneidge SA (1993) The Src family tyrosine kinases are required for platelet-derived growth factor-mediated signal transduction in NIH 3 T3 cells. Proc Natl Acad Sci USA 90:7696-7700.

Vieira AV, Lamaze C, Schmid SL (1996) Control of EGF receptor signaling by clathrin-mediated endocytosis. Science 274:2086-2089.

Vlahos CJ, Matter WF, Hui KY, Brown RF (1994) A specific inhibitor of phosphatidylinositol 3-kinase, 2-(4-morpholinyl)-8-phenyl-4H-1benzopyran-4-one (LY294002). J Biol Chem 269:5241-5248.

Vojtek AB, Cooper JA (1995) Rho family members: activators of MAP kinase cascades. Cell 82:527-529.

von Bohlen und Halbach F, Taylor J, Schachner M (1992) Cell typespecific effects of the neural adhesion molecules L1 and N-CAM on diverse second messenger systems. Eur J Neurosci 4:896-909.

Waskiewicz AJ, Cooper JA (1995) Mitogen and stress response pathways: MAP kinase cascades and phosphatase regulation in mammals and yeast. Curr Opin Cell Biol 7:798-805.

Xia Z, Dickens M, Raingeaud J, Davis RJ, Greenberg ME (1995) Opposing effects of ERK and JNK-p38 MAP kinases on apoptosis. Science 270:1326-1331.

Yang N, Higuchi O, Ohashi K, Nagata K, Wada A, Kangawa K, Nishida E, Mizuno K (1998) Cofilin phosphorylation by LIM-kinase 1 and its role in Rac-mediated actin reorganization. Nature 393:809-812.

Yip PM, Zhao X, Montgomery AM, Siu CH (1998) The Arg-Gly-Asp motif in the cell adhesion molecule L1 promotes neurite outgrowth via interaction with the alphavbeta3 integrin. Mol Biol Cell 9:277-290.

Zhao X, Yip PM, Siu CH (1998) Identification of a homophilic binding site in immunoglobulin-like domain 2 of the cell adhesion molecule L1. J Neurochem 71:960-971. 